\title{
DINAMIKA KELEMBAGAAN PERTANIAN ORGANIK MENUJU PEMBANGUNAN BERKELANJUTAN
}

\section{The Dynamics of Organic Farming Institution Towards Sustainable Development}

\author{
Hana Indriana $^{1)}$, Rilus A. Kinseng ${ }^{2)}$, Fredian Tonny ${ }^{3)}$, Anna Fatchiya ${ }^{4}$, \\ Tri Budiarto ${ }^{5)}$ Rohayati $^{6}$, Galuh Adriana ${ }^{7)}$ \\ ${ }^{1)}$ Departemen Sosiologi, Fakultas Ilmu Sosial dan Ilmu Politik, Universitas Indonesia \\ ${ }^{2,3,4)}$ Departemen Sains Komunikasi dan Pengembangan Masyarakat, Fakultas Ekologi Manusia, Institut Pertanian Bogor \\ 5) Program Studi Pembangunan Wilayah Perdesaan, Sekolah Pascasarjana, Institut Pertanian Bogor \\ 6),7) Program Studi Sosiologi Pedesaan, Sekolah Pascasarjana, Institut Pertanian Bogor \\ *)E-mail: hanaindriana@gmail.com
}

\begin{abstract}
The development of organic agriculture is significant both at local, national, regional, and global in the last two decades and organic farming has matured enough to offer lesson. In the process, these developments characterized by a variety of internal and external conflicts such as conflict of interest, the data conflicts, resource conflicts, and structural conflicts. Products from various conflicts between the actors who are related, ultimately forming institutional arrangements. This study aims to explain the mechanisms that made the actors involved in organic farming in managing conflicts by placing community as an important actor. This study uses a constructivist paradigm that seeks to understand the meaning construction management of conflicts of various actors. The study was conducted in three locations namely Tasikmalaya District, West Java, Boyolali, Central Java, and Malang in East Java. Conflict management model that has been built by the institutional organic farming in Tasikmalaya, Boyolali, and Malang a lesson learned for other lowland rice farming locations that could potentially be the location of the development of organic rice. In the development phase, while this institutional organic farming that have been built are encouraged to ensure food security where production is not only oriented to meet export demand, but also meet the needs of organic food at the local and national levels.
\end{abstract}

Keywords: conflict management, organic farming, sustainability, food security

\begin{abstract}
ABSTRAK
Perkembangan pertanian organik cukup signifikan baik di level lokal, nasional, regional, maupun global dalam dua dekade terakhir ini dan organic farming has matured enough to offer lesson. Pada prosesnya, perkembangan tersebut diwarnai oleh beragam konflik baik internal maupun eksternal berupa konflik kepentingan, konflik data, konflik sumber daya, maupun konflik struktural. Produk dari beragam konflik diantara aktor-aktor yang terkait tersebut, pada akhirnya membentuk aturan-aturan kelembagaan. Penelitian ini bertujuan untuk menjelaskan mekanisme yang dilakukan para aktor yang terlibat dalam pertanian organik dalam melakukan manajemen konflik dengan menempatkan komunitas sebagai aktor penting. Penelitian ini menggunakan paradigma konstruktivis yang berupaya untuk memahami konstruksi makna manajemen konflik dari berbagai aktor. Penelitian dilakukan di tiga lokasi yaitu Kabupaten Tasikmalaya Jawa Barat, Kabupaten Boyolali Jawa Tengah, dan Kabupaten Malang Jawa Timur. Model manajemen konflik yang telah dibangun oleh kelembagaan pertanian organik di Tasikmalaya, Boyolali, dan Malang menjadi pembelajaran bagi lokasi pertanian padi sawah lainnya yang berpotensi menjadi lokasi pengembangan padi organik. Pada fase pengembangan sementara ini, kelembagaan pertanian organik yang berhasil dibangun didorong untuk menjamin ketahanan pangan dimana produksi bukan hanya diorientasikan untuk memenuhi permintaan ekspor namun juga dapat memenuhi kebutuhan pangan organik di tingkat lokal dan nasional.
\end{abstract}

Kata kunci: manajemen konflik, pertanian organik, keberlanjutan, ketahanan pangan

\section{PENDAHULUAN}

\section{Latar Belakang}

Pertanian organik masih terus berkembang dan bertahan hingga saat ini di tengah gempuran modernisasi pertanian melalui revolusi hijau. Merujuk sejarah perkembangannya, pertanian organik ini muncul seiring merebaknya isu pembangunan berkelanjutan yang hingga saat ini pula menjadi perhatian masyarakat di seluruh dunia. Pada pertengahan tahun 1980, konsep keberlanjutan telah mendapat perhatian yang lebih besar sebagai kritik atas pendekatan industrial pada proses pembangunan pertanian. Adapun pertanian organik juga muncul sebagai salah satu implementasi dari pembangunan berkelanjutan tersebut (Sutanto, 2002). Pertanian organik menjadi penting bagi petani di seluruh dunia. Dan saat ini, pertanian organik "has matured enough to offer lessons" (Lockeretz, 2011). 
Pertanian organik terus berkembang secara signifikan baik di tingkat dunia, tingkat nasional, maupun tingkat lokal yang tampak dengan semakin bertambahnya luas lahan penanaman dan juga pertumbuhan pasar produk organik tersebut. Tercatat sampai tahun 2003, total luas lahan yang dikelola secara organik di dunia adalah 24 juta hektar. Total penjualan produk organik di seluruh dunia mencapai US\$ 23 miliar. Pasar produk organik utama dunia yaitu di Amerika Serikat dan Kanada juga semakin besar hingga mencapai 51 persen atau US\$ 11 miliar, disusul Eropa sebesar US\$ 10 miliar (46 persen), kemudian Jepang sebesar US\$ 350 juta. Pertumbuhan pasar produk organik diperkirakan mencapai 20-30 persen per tahun. Bahkan di beberapa negara tertentu mencapai 50 persen per tahun. Kenaikan nilai penjualan produk organik ini dipicu oleh harga premium dan tingkat kesadaran konsumen tentang mutu produk. Di Indonesia, produk pangan organik banyak diminati konsumen. Konsumen produk organik telah mencapai 10 persen dari jumlah penduduk. Pencapaian itu dirasa membanggakan di tengah gempuran produk kimia yang merajai pasaran saat ini. ${ }^{1}$ Di samping konsumen dan petani, berbagai pihak juga merespon isu pertanian organik ini. Baik pemerintah, lembaga-lembaga swadaya masyarakat maupun perusahaan-perusahaan turut mengambil peran dalam mengembangkan pertanian organik ini dengan beragam kepentingan yang melatarbelakanginya.

Pada perkembanganya, fluktuatifnya lahan organik terjadi sejak tahun 2007. Meningkat drastis di tahun 2008 dan terus menanjak hingga tahun 2010, kemudian bergerak turun hingga tahun 2012 dan mulai merangkak naik di tahun 2013, dari luas 212.696,65 di tahun 2012 (Tabel 1). Lahan yang disertifikasi LSO Nasional adalah seluas 24.964,14 Ha (33\%), sedangkan lahan yang disertifikasi oleh LSO Internasional adalah seluas 51.049,06 Ha (67\%). Perjalanan organik Indonesia dari mulai program pemerintah, pendampingan lembaga-lembaga swadaya masyarakat, disahkannya LSO nasional menjadi penentu fluktuasi luasan lahan organik yang disertifikasi. Peningkatan luas lahan merupakan buah dari dukungan pemerintah untuk pertanian organik yang semakin baik dari tahun ke tahun. Salah satunya adalah keputusan DPR-RI periode 2004-2009 untuk mengalihkan sebagian pupuk kimia menjadi pupuk organik. Selain itu, dukungan pun tampak pada alokasi APBN khususnya Pembinaan dan Sertifikasi Pangan Organik serta diresmikannya Permentan. Peraturan Pemerintah Nomor byang memiliki jaminan atas integritas organik yang dihasilkan. Pemerintah daerah banyak yang memperluas wilayahnya dengan program pertanian organik, salah satu buktinya adalah banyaknya pemerintah daerah yang memberikan subsidi untuk petani melakukan sertifikasi.

Pertanian organik dirancang pengembangannya dalam enam tahapan mulai dari tahun 2001 hingga tahun 2010 mulai dari tahap sosialisasi, sosialisasi dan regulasi, regulasi dan bantuan teknis, bantuan teknis dan sertifikasi, sertifikasi dan promosi pasar, industrialisasi dan perdagangan. Perkembangan yang masih dirasakan belum optimal mendorong "Go Organik 2014" kembali diluncurkan. Peraturan Menteri Pertanian Nomor 64/Permentan/OT.140/5/2013 tentang Sistem Pertanian Organik disusun sebagai basis regulasi dalam rangka penguatan pengembangan kelembagaan sistem pertanian organic di Indonesia ke depan.

Kelahiran beberapa organisasi non-pemerintah (ornop)

1. Very Herdiman. Berjuang Memperkenalkan Makanan Organik. Jurnal Nasional, Minggu, 27 April 2008.
Tabel 1. Luas Area Organik Indonesia 2013

\begin{tabular}{lr}
\hline Tipe Area Pertanian Organik & Luas (Ha) \\
\hline Area disertifikasi & $76.013,20$ \\
Area dalam proses sertifikasi & 31,38 \\
Area dengan sertifikasi PAMOR & 36,00 \\
Area tanpa sertifikasi & $144.220,05$ \\
\hline Total & $220.300,62$ \\
\hline Sumber : SPOI Aliansi Organis Indonesia, 2013
\end{tabular}

yang peduli lingkungan pada akhir pemerintahan orde baru membawa angin segar bagi gerakan pertanian organik melalui pemberdayaan masyarakat pertanian. Adapun pertanian organik yang dilakukan oleh petani-petani di Indonesia mulai berkembang di tahun 1999 dengan diinisiasi oleh berbagai lembaga swadaya (LSM). Masyarakat petani di beberapa pedesaan di Indonesia khususnya di Jawa sudah merubah sistem pertanian mereka dari sistem pertanian non organik menjadi sistem pertanian organik (Wangsit, 2003; Kartini, 2005).

Seiring perkembangan tersebut, kini tidak hanya pihak pemerintah, lembaga-lembaga swadaya masyarakat dan petani saja yang bergerak dalam pertanian organik. Kini berdiri pula lebih dari 117 perusahaan yang menangkap adanya peluang usaha dalam pertanian organik ${ }^{2}$. Bisnis usaha komoditi organik pun menjadi trend. Hal ini tidak terlepas dengan adanya potensi permintaan produk organik yang sebanding dengan kesadaran konsumen terhadap pangan yang sehat dan alami ${ }^{3}$. Sehubungan dengan itu, dengan respon yang semakin besar dari para pelaku pertanian maka sistem pertanian organik pun semakin berkembang hingga saat ini baik di tingkat global maupun konteks lokal.

Sistem pertanian organik adalah sistem pertanian yang meliputi cara produksi, aturan, dan nilai yang melandasi, hubunganhubungan social yang terbentuk dengan diterapkannya sistem pertanian organic ini sebagai upaya pengelolaan sumber daya lahan pertanian yang menjamin keberlanjutan lingkungan (Rientjes, 1992). Sistem tersebut memiliki beberapa keunggulan dibandingkan dengan pertanian non-organik atau pertanian modern seperti turut menjamin kelangsungan ekosistem pertanian, biaya produksi lebih hemat dengan harga jual yang lebih tinggi, produknya lebih sehat, menjamin keberlanjutan, turut membangun kemandirian petani, dan berperspektif gender. Jadi, pertanian organik memberi manfaat baik dari aspek ekologi, sosial, budaya, dan ekonomi.

Petani organik dalam pergerakannya mengalami isolasi dan bahkan sering berada daklam konflik. Pada prosesnya, perkembangan pertanian tersebut diwarnai oleh beragam konflik baik internal maupun eksternal berupa konflik kepentingan, konflik data, konflik sumber daya, maupun konflik struktural. Beberapa konflik yang muncul dalam perkembangan pertanian organik menurut Lockeretz (2011) mengemukakan salah satunya adalah konflik internal dalam organisasi yang melakukan advokasi pertanian organik untuk bekerja sama dengan organisasi yang memiliki motivasi yang sama sehingga organisasi menjadi kurang efektif. Menurut

2. Direktori Pertanian Organik. http://agribisnis.deptan.go.id/ Pustaka/Bab2-03-direktori\%zotaniorganik.pdf

3. Wacana Organis, Edisi No. 5/Th2 (Desember 2003 - Februari 2004) 
Howard dalam Lockeretz (2011), juga terdapat konflik antara fresh, natural foods and agribusiness profit. Konflik tersebut berupa pertarungan antara keuntungan agribisnis dengan sistem industrial dengan sistem pertanian organik yang mengutamakan kealamian dan kesegaran pangan. Perhatian yang masih relatif kecil terhadap pertanian organik dimana terdapat konflik antara ukuran-ukuran komoditas dan ukuran-ukuran lingkunganlingkungan bernuansa pertanian. Menurut Kallander dalam Lockeretz (2011), dalam perkembangnnya konsumen seringkali terkait pada kelompok-kelompok lokal maupun regional, dan produk-produknya masih dalam skala yang sangat kecil, dijual secara langsung melalui pasar lokal, toko-toko pertanian, dan boks boks distribusi. Melalui prosedur kelembagaan yang demokratis, organisasi-organisasi menciptakan dasar nilai-nilai dan tujuan-tujuan yang menarik orang dan semakn banyak orang baik petani maupun non petani.

Selain itu, adanya konflik kepentingan dalam organisasiorganisasi atau lembaga sertifikasi, dimana lembaga-lembaga tersebut menjadi penting dalam menentukan standar organik baik dalam proses budidaya maupun produk yang dihasilkannya. Standar itulah yang kemudia lebih menentukan pasar (market driven), dan ideologi berbasis anggota lebih merasa bahwa nilai-nilai organik being diluted (menjadi cair, tipis). Terlebih ketika salah satu lembaga sertifikasi yang menjadi rujukan pengembangan pertanian organik (contohnya EFA di Sweden) seringkali dipertimbangkan sebagai green fundamentalists, dan sesekali merasa termarginalisasi dalam proses-proses sertifikasi.

Adapun produk dari beragam konflik diantara aktor-aktor yang relevan tersebut, menurut pada akhirnya membentuk aturanaturan kelembagaan (Knight, 2009). Untuk menciptakan kelembagaan yang berkelanjutan maka membuka ruang konflik antara tujuan dan nilai-nilai pertanian organik dengan tujuan dan nilai-nilai pembangunan sosial ekonomi yang lebih luas. Tidak mudah untuk mengatasi konflik antara pertanian organik dann konvensional dimana pertanian konvensional sudah mendominasi bertahun tahun bahkan sudah menjadi identitas bagi masyarakat di beberapa negara. Sehubungan itu maka penelitian mengenai manajemen konflik dalam yang dilakukan oleh para aktor yang terlibat dalam sistem pertanian organik dalam rangka membangun kelembagaan pertanian organik berkelanjutan menuju ketahanan pangan penting untuk dilakukan.

\section{Perumusan Masalah}

Berdasarkan uraian latar belakang yang telah dikemukakan maka perumusan masalah penelitian adalah bagaimanakah mekanisme manajemen konflik yang dilakukan oleh para aktor yang terlibat dalam sistem pertanian organik dalam rangka membangun kelembagaan pertanian organik berkelanjutan menuju ketahanan pangan?

Adapun pertanyaan penelitian diuraikan sebagai berikut :

1. Siapa sajakah actor yang terlibat dalam system pertanian organic pada kondisi terkini?

2. Bagaimanakah bekerjanya norma dan pola-pola relasi antar actor sehingga menunjukkan kelembagaan-kelembagaan yang terbangun dalam system pertanian organic pada kondisi terkini?

3. Faktor-faktor apa sajakah yang mempengaruhi keberlanjutan kelembagaan yang terbangun dalam system pertanian organic tersebut?

4. Konflik apa sajakah yang dihadapi oleh komunitas petani organic dengan actor lainnya dan bagaimanakah komunitas bersama actor lainnya melakukan manajemen konflik dalam konteks pengembangan system pertanian organic tersebut?

5. Bagaimanakah tingkat ketahanan pangan khususnya padi organic di lokasi penelitian?

Tujuan Penelitian pada Tahun 1 :

1. Mengidentifikasi dan pemetaan actor yang terlibat dalam system pertanian organic pada kondisi terkini

2. Mengidentifikasi dan menganalisis kelembagaan yang terbangun dalam system pertanian organic pada kondisi terkini

3. Mengidentifikasi dan menganalisis faktor-faktor yang mempengaruhi keberlanjutan kelembagaan yang terbangun dalam system pertanian organic

4. Mengidentifikasi dan menganalisis konflik dalam pengembangan system pertanian organic

5. Menganalisis tingkat ketahanan pangan khususnya padi organic di lokasi penelitian

6. Merumuskan model manajemen konflik berbasis komunitas dalam rangka membangun kelembagaan pertanian organic berkelanjutan menuju ketahanan pangan

Adapun tujuan penelitian pada Tahun 2 yaitu :

1. Mengidentifikasi actor dan kelembagaan dalam Sistem Pertanian Non Organik di sekitar lokasi penelitian

2. Mensosialisasikan dan mengimplementasi manajemen konflik berbasis komunitas dalam rangka perluasan system pertanian organic menuju ketahanan pangan

\section{TINJAUAN PUSTAKA}

Kajian mengenai kelembagaan dari perspektif sosiologis dalam sistem pertanian organik belum banyak dilakukan. Kajian mengenai kelembagaan dari perspektif sosiologis dalam sistem pertanian organik belum banyak dilakukan. Namun, beberapa hasil penelitian menunjukkan bahwa sistem pertanian organic mengindikasikan terbangunnya proses-proses inklusi dimana petani memperoleh ruang kehidupannya kembali seperti dengan munculnya nilai-nilai kolektivitas dalam penerapan pertanian organic. Hasil penelitian Indriana (2010:160) menunjukkan bahwa bentuk-bentuk kelembagaan dalam sistem pertanian padi sehat yang sama dengan kelembagaan pada sistem pertanian padi non-organik yaitu kelembagaan penguasaan lahan, kelembagaan hubungan kerja, dan kelembagaan panen. Perbedaan tampak dengan adanya mekanisme yang membentuk kelembagaan penyedia pupuk dan pestisida, kelembagaan Koperasi Kelompok Tani "Penyedia sarana pertanian", kelembagaan penyuluhan, kelembagaan pasca panen, dan kelembagaan distribusi beras SAE sebagai produk dari padi sehat. Terbangunnya kelembagaan-kelembagaan tersebut menjadi ruang bagi para petani untuk membangun kembali semangat kegotongroyongan, nilai kerjasama, nilai memaksimalkan keuntungan baik secara ekonomi dari hasil produksi produk organic, secara social dengan menguatnya nilai-nilai kolektivitas, dan secara ekologi dengan penerapan teknik pertanian yang ramah terhadap lingkungan.

Pada tahun 2009, dari hasil penelitiannya Best menjelaskan bahwa sosiolog melakukan pendekatan terhadap pertanian organik dari beragam orientasi teoritis. Meskipun pertanian secara tipikal menjadi kajian pada sosiolog dengan fokus pada produksi, kajian pertanian organik merupakan pertalian antara produksi dengan konsumsi. Konsumen menciptakan permintaan dan upaya pemenuhan permintaan pasar dan produksi yang 
berkelanjutan. Sementara pada tahun 2010, hasil penelitian Indriana (2010) terkait dengan kelembagaan, diketahui bahwa bentuk-bentuk kelembagaan yang terdapat dalam sistem pertanian padi sehat yaitu kelembagaan untuk pengaturan input, kelembagaan untuk pengaturan produksi, dan kelembagaan untuk pengaturan output. Pada prosesnya, kelembagaankelembagaan yang terbentuk dalam sistem pertanian padi sehat cenderung lebih ditopang oleh pilar normatif dan regulatif. Akan tetapi, penelitian tersebut lebih berfokus pada kajian di level mikro dimana berada pada posisi untuk mengidentifikasi dan memetakan kelembagaan-kelembagaan dalam sistem pertanian organic yang ada pada konteks lokasi dan komunitas setempat. Berdasarkan hasil penelitian Best (2009) dan Indriana (2010) maka perkembangan sistem pertanian organic sebagai perubahan cara produksi serta tata aturan sebagai pilar-pilar kelembagaan meliputinya membuka ruang bagi terjadinya proses-proses inklusi social yang dibangun oleh para aktor khususnya dan masyarakat terlibat sehingga memperbesar pengaruh positif dari sistem pertanian organic tersebut terhadap kehidupan masyarakat.

Merujuk pada pendekatan sistem, maka pertanian organik merupakan melibatkan cara, norma, nilai, tata aturan dan polapola relasi aktor yang membangun pertanian organik tersebut. dari pendekatan konsep kelembagaan, maka pengembangan pertanian organik mencakup seperangkat norma, nilai, tata aturan yang mendasari pola-pola hubungan yang bersifat ajeg dan bertahan dalam jangka waktu tertentu. Sebagaimana penelitian Indriana (2010), pengembangan pertanian padi sehat yang merujuk pada upaya menerapkan sistem pertanian organik menunjukkan adanya perubahan 1) aktor yang terlibat, 2) peran yang dimainkan oleh para aktor, 3) pola-pola relasi antar aktor sehingga membangun kelembagaan dalam pertanian organik, 4) terbangunnya kelembagaan-kelembagaan yang sebelumnya tidak terbangun dalam sistem pertanian non organik.

Perkembangan pertanian organik di Kampung Ciburuy pada tahun 2010 berbeda dengan perkembangan beberapa wilayah pengembangan pertanian organik pada tahun 2014 ini. Pada tahun ini, beberapa wilayah pengembangan pertanian organik seperti halnya di Tasik, Magelang, Sragen, Boyolali dan sebagainya sudah berhasil mengekspor produk organiknya ke luar negeri sehingga mengindikasikannya kemampuan para aktor lokal dan nasional dalam membangun jejaring dengan aktor di tingkat global. Dengan semakin meluasnya pola-pola relasi yang dibangun oleh para aktor, maka semakin membuka peluang keberhasilan pertanian organik untuk mencapai tujuannya. Tujuan yang ingin dicapai oleh pertanian organik tersebut secara agregat merupakan langkah upaya untuk mewujudkan pembangunan pertanian yang berkelanjutan.

\section{Ruang Lingkup Konflik dan Manajemen Konflik Berbasis Komunitas}

Sebagaimana telah dikemukakan bahwa tidak mudah untuk mengatasi konflik antara pertanian organik dan konvensional dimana pertanian konvensional sudah mendominasi bertahun tahun bahkan sudah menjadi identitas bagi masyarakat di beberapa negara (Lockeretz, 2011). Terlebih dinamika konflik yang terjadi dalam perkembangan pertanian organic memiliki beragam bentuk. Tonny (2014) mengemukakan bahwa konflik sering terjadi oleh karena perbedaan cara pandang diantara pihak-pihak yang berkonflik. Masing-masing orang, kelompok, dan unit sosial lainnya memiliki pengalaman yang berbeda, cara hidup yang khas, dan memiliki nilai yang berbeda dengan unit sosial lainnya. Perbedaan-perbedaan ini mengakibatkan cara pandang yang khas tentang sesuatu, yang berbeda dengan yang lainnya.

Konflik adalah benturan yang terjadi antara dua pihak atau lenih yang disebabkan adanya perbedaan, nilai, status, kekuasaan dan kelangkaan sumber daya. Konflik dan kehidupan warga komunitas sangatlah sulit untuk dipisahkan dan keduanya berada bersama-sama karena perbedaan nilai, status, kekuasaan, dan keterbatasan sumber daya itu memang selalu terjadi. Konflik akan selalu dijumpai dalam kehidupan manusia, warga komunitas, dan masyarakat sebab untuk memenuhi kebutuhan hidupnya, manusia atau warga komunitas melakukan berbagai usaha yang dalam pelaksanaannya selalu dihadapkan pada sejumlah hak dan kewajiban. Apabila hak yang dimiliki seseorang merupakan bagian dari hak sekelompok orang (komunal), atau bila hak itu memerlukan pengakuan oleh orang lain, maka dalam merealisasikannya dapat menimbulkan benturan-benturan. Benturan akan semakin tampak, terutama apabila terdapat rasa tidak adil dalam merealisasikan hak tersebut, dan faktor inilah yang merupakan pemicu bagi konflik atau sengketa yang kemudian timbul.

Kata konflik seringkali mengandung konotasi negatif, yang cenderung diartikan sebagai lawan kata dari pengertian kerjasama, harmoni, dan perdamaian. Konflik acapkali diasosiasikan dengan kekerasan atau ancama kekerasan. Pandangan yang dangkal mengenai konflik yang demikian, sulit untuk diubah, walau konflik sebenarnya perlu dimaknai sebagai suatu ekspresi perubahan masyarakat. Konflik bukanlah suatu yang dapat dihindari atau disembunyikan tetapi harus diakui keberadaannya, dikelola, dan diubah menjadi suatu kekuatan bagi perubahan positif. Konflik dapat timbul di antara individu satu dengan yang lain (antarindividu) dan antarkelompok individu. Konflik antarindividu meliputi : (1) antara individu dengan individu lain dari kelompok yang berbeda, misalnya seorang warga suku dengan seorang warga suku yang lain; dan (2) antara individu-individu dalam satu kelompok, misalnya perebutan tanah antar anggota suku, yang disebut pula konflik interhouse atau intergenerational. Sedangkan yang termasuk ke dalam konflik antar-kelompok (intra group atau intrahouse) dapat berupa konflik antar sub-sub kelompok yang otonom dalam satu kelompok, dan konflik antar-kelompok besar yang otonom dalam komunitas atau masyarakat.

Fisher dan kawan-kawan (2001) juga mengemukakan teori penyebab terjadinya konflik, yaitu teori kebutuhan manusia, yang beranggapan bahwa konflik disebabkan oleh kebutuhan dasar manusia (fisik, mental, dan sosial) yang tidak terpenuhi atau dihalangi. Dengan pengertian ini, cara menangani konflik adalah (a) membantu pihak-pihak yang berkonflik untuk mengenali dan mengupayakan bersama kebutuhan mereka yang tidak terpenuhi, dan (b) agar pihak yang mengalami konflik mencapai kesepakatan untuk memenuhi kebutuhan dasar semua pihak; Adapun teori identitas, yang melihat konflik disebabkan identitas yang terancam. Untuk mengatasi konflik menurut teori ini adalah (a) melakukan lokakarya dan dialog antara pihakpihak yang mengalami konflik, dan (b) menemukan kesepakatan bersama yang mengakui kebutuhan identitas pokok semua pihak.

Pada hakekatnya pemaknaan terhadap istilah penyelesaian konflik, sepenuhnya tergantung dari pihak-pihak yang 
berkepentingan; baik mengenai pilihan-pilihan yang diambil, maupunmengenai hasilyang diharapkan dariprosespenyelesaian itu. Sedangkan istilah berbasis komunitas berarti bahwa proses diletakkan pada (dan sebagai respon yang mengandung unsur-unsur kepastian dari) kebutuhan komunitas itu sendiri. Komunitas akan membutuhkan perangkat manajemen konflik khususnya ketika konflik tereskalasi sedemikiamn rupa, dan menimbulkan kondisi yang tegang dan penuh ketidakpastian.

Pengembangan manajemen konflik harus praktis, efisien, efektif, dan berkelanjutan karena pengertian komunitas mencakup makna dan fungsinya yang luas. Komunitas mengandung pengertian yang berkaitan dengan suatu tempat di mana orang berada, di mana orang bekerja, di mana orang berinteraksi, dan di mana tempat orang berasal (lokalitas). Sehubungan dengan pengertian yang demikian, maka proses $\mathrm{CBCM}$ harus menyeluruh (inklusif), tanpa pembatasan (unlimited), dan secara nyata dibicarakan dan diterapkan (applicable). Proses akhir dari CBCM adalah terlaksananya pertemuan antar pihak-pihak yang berkonflik, dan menggunakan forum tersebut sebagai aktivitas yang nyata-nyata membicarakan sesuatu hal yang pasti, tidak didasarkan pada issue atau desas-desus. Aktivitas semacam itu merupakan suatu peluang untuk mempertemukan berbagai perbedaan yang ada, dan menjadi awal proses penyelesaian konflik yang terjadi. Berkumpul dan saling berbicara akan dapat memunculkan pengalaman-pengalaman mengenai berbagai latar belakang dan kepentingan, sehingga dapat menggambarkan struktur konflik yang ada menuju penyelesaiannya.

Adapun produk dari beragam konflik diantara aktor-aktor yang relevan tersebut, menurut pada akhirnya membentuk aturanaturan kelembagaan (Knight, 2009). Untuk menciptakan kelembagaan yang berkelanjutan maka membuka ruang konflik antara tujuan dan nilai-nilai pertanian organik dengan tujuan dan nilai-nilai pembangunan sosial ekonomi yang lebih luas.

\section{Kelembagaan yang Berkelanjutan dalam Sistem Pertanian Organik}

Hagedorn dalam Padmabadhan (2009) merumuskan empat strategi dasar untuk mencapai "kelembagaan keberlanjutan" dalam jangka panjang: (1) memunculkan refleksivitas yang dibangun di atas penguatan sensitivitas aktor untuk mendorong reformasi kelembagaan; (2) mengorganisasikan diri dan berpartisipasi dalam proses politik yang memberi dampak integratif; (3) menciptakan harmonisasi kepentingan dan regulasi konflik yang merupakan pusat penyeimbangan kekuasaan dan kontrol atas sumber daya, sehingga membutuhkan investasi dalam pengembangan mekanisme penyelesaian konflik; dan (4) memunculkan inovasi kelembagaan sebagai proses kreatif mencari dan belajar menggunakan pendekatan kooperatif. Sejalan dengan Haberer (1996), Hagedorn et al. (2002) merumuskan pentingnya menciptakan transparansi dalam pengaturan kelembagaan .

Kelembagaan dalam konteks pembangunan berkelanjutan dari perspektif sosiologi, terkait dengan dimensi manusia sebagai fokus dalam pembangunan, sehingga jika untuk mengkonseptualisasikan pembangunan berkelanjutan dari dimensi manusia, maka akan dititikberatkan pada keberlanjutan sistem sosial masyarakat. (Gale and Corday, 1994). Para sosiolog akan menempatkan keberlanjutan sistem sosial, partisipasi dan pemberdayaan sebagai poin penting dalam mengklarifikasi pembangunan yang berkelanjutan tersebut
(Gale and Corday, 1994, and Lele, 1991). Sehubungan dengan itu, keberlanjutan sistem sosial diinterprestasikan sebagai keberlanjutan kelembagaan.

Menurut Cernea(1993), dalam perspektif sosiologi, terdapat dua elemen yang dapat menjadi alat untuk mencapai pembangunan yang berkelanjutan yakni adanya pengorganisasian sosial (social organization) dan teknik sosial (social techniques). Pertama, pengorganisasian sosial merupakan bangunan sosial yang mencakup para pelaku sosial itu sendiri; kontrak sosial yang mengatur hubungan antara masyarakat lokal dengan para stakeholder; hak-hak pengelolaan sumber daya alam yang merujuk pada sistem budaya setempat, meliputi hak kepemilikan, penguasaan, atau penentuan orang yang memiliki peran sebagai "public building"; sistem otoritas dan mekanisme penguatan kepatuhan; ketiadaan batas-batas antara selang pengorganisasian produksi dari sistem berbasis keluarga menjadi perusahaan besar; pertukaran jaringan tenaga kerja; termasuk nilai dan sistem kepercayaan setempat. Kedua, adanya teknik sosial untuk membangun kesadaran publik hingga berinvestasi dalam membangun modal sosial, dari konsultasi-konsultasi sederhana hingga membangun pengelolaan partisipatif, dari sistem insentif hingga kontrol kelembagaan, dari tradisi hingga merubah praktik lama dan memperkenalkan inovasi baru, dari pemberdayaan hingga membentuk kohesi sosial, dari perilaku individu yang bermotif ekonomi hingga membangun kekuatan solidaritas, kepercayaan, pengorganisasian diri dan penerimaan nilai-nilai kelompok.

Adapun merujuk pada Tonny (2004), tingkat keberlanjutan kelembagaan komunitas lokal dapat dianalisis dari faktorfaktor internal dan eksternal sebagai faktor-faktor penentu yang mempengaruhi keberlanjutan kelembagaan komunitas lokal. Komunitas lokal tersebut juga mencakup komunitas petani padi sawah. Faktor-faktor eksternal yang dimaksud adalah meliputi (1) intervensi pemerintah yang berdampak positif, (2) intervensi pemerintah yang berdampak negatif, (3) Ketersediaan sarana dan prasarana umum, dan (4) jejaring kerjasama antar kelembagaan. Sedangkan faktor-faktor internal mencakup (1) kepemimpinan, (2) pendidikan anggota, (3) aturan tertulis, (4) aturan tidak tertulis, (5) ukuran kelembagaan, (6) usia kelembagaan, (7) kecukupan anggaran, dan (8) proses pendirian kelembagaan.

\section{Pencapaian Ketahanan Pangan dan Kerangka Sustainable Development Goals (SDGs)}

Pada fase pengembangan sementara ini, kelembagaan pertanian organic yang berhasil dibangun masih didorong untuk menjamin ketahanan pangan dimana produksi bukan hanya diorientasikan untuk memenuhi permintaan ekspor namun juga dapat memenuhi kebutuhan pangan organic di tingkat lokal dan nasional.Tujuan ketahanan pangan adalah tersedianya pangan dan jumlah dan kualitas yang cukup, terdistribusi dengan harga terjangkau,serta aman dikonsumsi. Ketahanan pangan harus inherent dalam kebijakan pembangunan nasional, bukan program-program yang reaktif atau hanya program "pemadam kebakaran". Komponennya adalah yaitu ketersediaan, distribusi, dan konsumsi. Ada yang menyebut ada 3 dimensi yaitu ketersediaan (availability), akses (access), dan pemanfaatan (utilization). Menurut UU No.18 tahun 2012 tentang pangan, "Ketahanan Pangan" adalah kondisi terpenuhinya pangan bagi negara sampai dengan perseorangan, yang tercermin dari tersedianya pangan yang cukup, baik jumlah maupun mutunya, aman, beragam, bergizi, merata, dan terjangkau serta 
tidak bertentangan dengan agama, keyakinan, dan budaya masyarakat, untuk dapat hidup sehat, aktif, dan produktif secara berkelanjutan. Pengertian ketahanan pangan tersebut sejalan dengan tujuan sustainable develolment goals yaitu pada Goal 2. Yaitu End hunger, achieve food security and improved nutrition, and promote sustainable agriculture dimana secara rinci tujuan tersebut mentargetkan "by 2030 ensure sustainable food production systems and implement resilient agricultural practices that increase productivity and production, that help maintain ecosystems, that strengthen capacity for adaptation to climate change, extreme weather, drought, flooding and other disasters, and that progressively improve land and soil quality".

Lebih lanjut, sebagai kerangka pemikiran dirumuskan bahwa dinamika konflik merupakan proses membangun kelembagaan. Kelembagaan adalah hasil akhir dari konflik. Dinamika konflik dipengaruhi oleh factor eksternal dan factor internal. Proses terbangunnya kelembagaan yang berkelanjutan mendukung upaya ketahanan pangan. Tingkat ketahanan pangan tersebut diindikasikan oleh jumlah pangan yang cukup, kualitas cukup, distribusi merata, harga terjangkau, aman dikonsumsi (Gambar 2).

\section{METODE PENELITIAN}

\section{Waktu dan Tempat}

Penelitian dilakukan di 3 komunitas petani padi organik yang tergabung ke dalam keanggotaan gabungan kelompok tani organic di wilayah setempat yaitu di Kabupaten Tasik Malaya, Jawa Barat; Kabupaten Boyolali, Jawa Tengah; dan Kabupaten Malang, Jawa Timur. Dua komunitas petani yaitu di Tasikmalaya dan di Boyolali sudah mengekspor padi organiknya ke luar negeri seperti Amerika, Belgia, sedangkan di Malang sedang dalam proses persiapan ekspor ke luar negeri. Penelitian lapang sudah dilakukan sejak bulan Maret dari proses penjajagan lapang, wawancara, hingga focuss group discussion.

\section{Teknik Pengambilan Sampel}

Informan dipilih berdasarkan pengetahuan, pengalaman, dan keterlibatannya dalam system pertanian padi organic di masing-masing lokasi penelitian. Informan tersebut yaitu Dinas Pertanian Tanaman Pangan dari kabupaten terkait, Dinas Perdagangan, pihak perusahaan yang turut berkontribusi, pihak LSM dan akademisi yang turut mendampingi komunitas padi organic di lokasi penelitian. Sedangkan subyek penelitian yang diteliti sebagai kasus adalah para petani organic yang sudah terlibat dalam pertanian organic sejak awal perkembangannya sampai saat ini sehingga dapat menjelaskan dinamika dan mekanisme manajemen konflik yang dialami seperti halnya ketua kelompok, tokoh pertanian, ketua dan pengurus kelompok tani. Adapun sampel dalam penelitian ini yaitu para petani organic yang menjadi pemilik lahan atau petani penggarap yang memiliki hak mengambil keputusan pada lahan pertaniannya. dari setiap lokasi penelitian dipilih 30 orang responden secara acak.

\section{Jenis dan Teknik Pengambilan Data}

Jenis data yang diambil berupa data primer dan sekunder. Data sekunder berupa perundangan pemerintah tentang pertanian organik, data dari dinas pertanian dan perdagangan di tingkat kabupaten, data lembaga gabungan kelompok tani, data kelompok tani, data monografi desa, dan berbagai literature baik buku teks, jurnal, maupun laporan-laporan penelitian. Data primer diambil melalui wawancara mendalam dan focus group discussion (FGD) untuk mengidentifikasi dan memetakan actor, relasi actor, kelembagaan dan keberlanjutannya dinamika konflik dan mekanisme manajemen konflik dalam pengembangan pertanian organic. Adapun data primer mengenai factor-faktor yang mempengaruhi keberlanjutan kelembagaan dan tingkat ketahanan pangan akan diperoleh dari pengisian kuesioner oleh para responden.

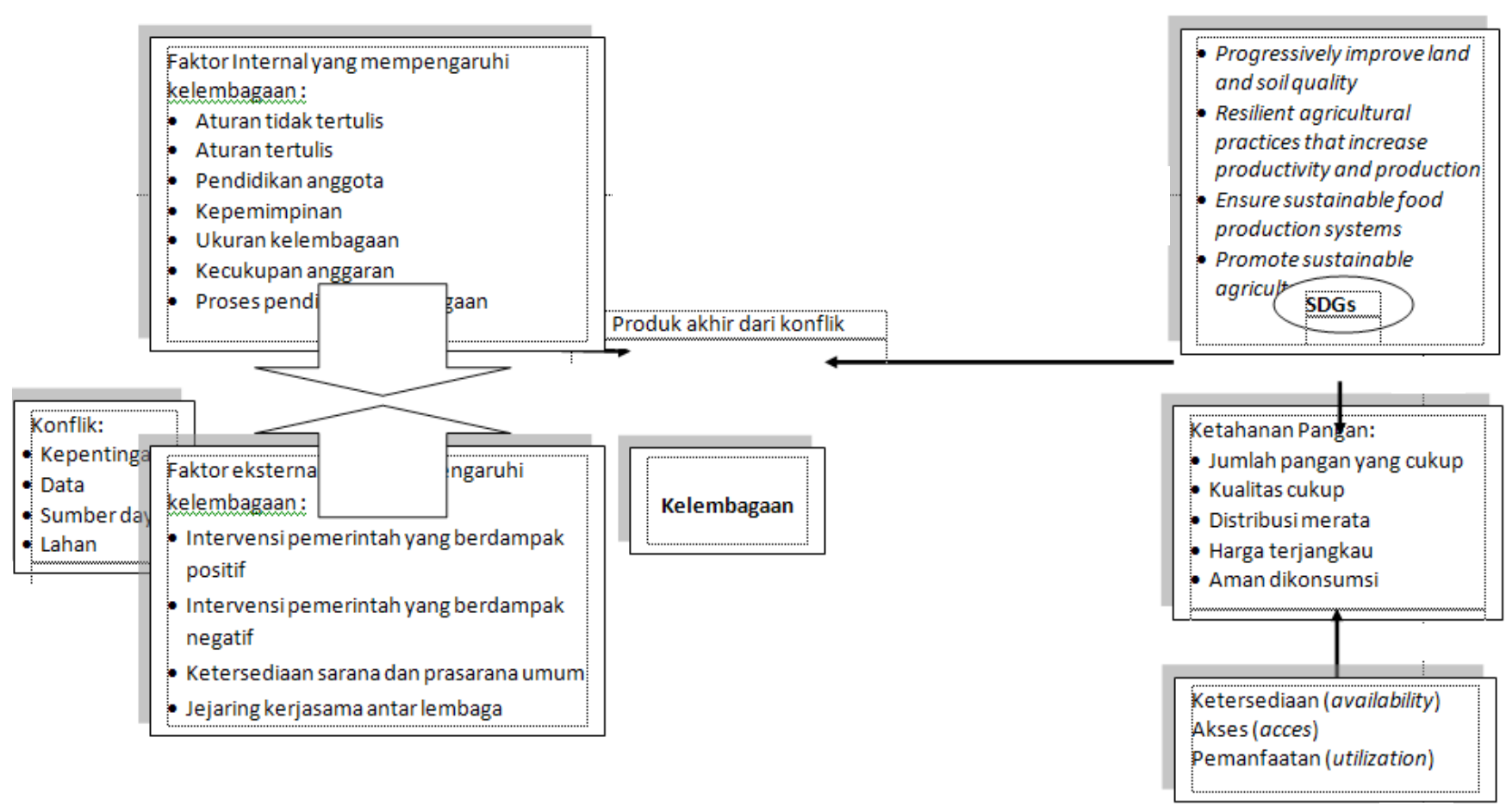

Gambar 2. Kerangka Pemikiran Manajemen Konflik Berbasis Komunitas dalam Rangka Membangun Kelembagaan Pertanian Organik yang Berkelanjutan Menuju Ketahanan Pangan 


\section{Pengolahan dan Analisis Data}

Data yang sudah terkumpul berupa data primer Pengolahan data factor-faktor yang mempengaruhi keberlanjutan kelembagaan dan tingkat ketahanan akan menggunakan metode uji statistik sementara data kelembagaan menggunakan metode diagram venn. Data mengenai actor, relasi actor, kelembagaan, manajemen konflik akan dianalisis secara deskriptif. Hasil uji validitas dan reliabilitas terlampir (Lampiran 1)

\section{Gambaran Umum Lokasi Penelitian}

Dalam hal ini, terdapat tiga daerah yang dijadikan tempat penelitian yaitu Tasikmalaya, Malang, dan Boyolali. Pertama yang dibahas yaitu mengenai kecamatan di daerah tasik. Kecamatan yang menjadi fokus penelitian ini ada empat kecamatan, yaitu Kecamatan Salawu, Kecamatan Manonjaya, Kecamatan Sukahening dan Kecamatan Cisoyong. Kecamatan Cisayong dan Manonjaya berada di ketinggian 0-500 mdpl, Kecamatan Salawu ada ketinggian 500-1000 mdpl, dan Kecamatan Sukahening berada di ketinggian 2000-2500 mdpl. Luas lahan pertanian pada masing-masing kecamatan berbeda, dan terbagi menjadi dua kategori yaitu untuk non pertanian dan pertanian. Luas lahan dari keempat kecamatan tersebut hampir setengahnya merupakan lahan untuk pertanian, dan hanya sedikit yang digunakan untuk non pertanian. Luas lahan pertanian Kecamatan Salawu mencapai 4.493 ha, dengan lahan bukan pertaniannya hanya 557 ha. Kecamatan Manonjaya mencapai 7503 ha, dengan lahan bukan pertaniannya 860 ha, Kecamatan Cisayong mencapai 5.690 ha, dengan dengan lahan bukan pertaniannya 250 ha. Terakhir untuk Kecamatan Sukahening mencapai 2.597 ha, dengan lahan bukan pertaniannya 245 ha. Untuk lahan sawah di kecamatan salawu, luasnya mencapai 1.532 ha dan bukan sawahnya 2.961 ha, kecamatan manonjaya luas sawahnya mencapai 870 ha, dan bukan sawahnya 2.211 ha, kecamatan 1.749 ha, dan bukan sawahnya 3.941 ha, serta kecamatan sukahening mencapai 926 ha, dan bukan sawah 1.671 ha. Pada pertanian padi sawah, luas tanam, luas panen, produksi dan produktivitasnya berbeda. Menurut data tahun 2014, kecamatan salawu luas tanamnya mencapai 3.748 ha, dengan luas panen 3.753 ha, dan produksinya mencapai 27.881 ton, dengan produktivitasnya mencapai 74,29. Untuk kecamatan manonjaya, luas tanam mencapai 1.839 ha, dengan luas panen mencapai 1.898 ha, dan produksi mencapai 12931 ton, dengan produktivitasnya 68,13 . Untuk kecamatan cisayong luas tanamnya mencapai 5.026 ha, luas panen 5.219 ha, dan produksinya mencapai 34.873 ton dengan produktivitas 66,82 . Untuk kecamatan sukahening, luas tanam mencapai 2.333 ha, luas panen 2.339 ha, dan produksi mencapai 15.800 ton, dan produktivitasnya 67,55 .

Selanjutnya yaitu Kecamatan Lawang di wilayah Kabupaten Malang. Kecamatan lawang berada di kabupaten malang, dan berada pada ketinggian 527 dari laut, serta dengan 2 kelurahan dan 10 desa. Kecamatan lawang memiliki 26.505 rumah tangga, dengan jumlah laki-laki sebanyak 51.626 jiwa, dan perempuan 51.776 jiwa. Dari total luas lahan kecamatan lawang, yang dijadikan pemukiman seluas 221 ha, sawah seluas 704 ha, kebun seluas 3.074 ha, dan areal perkebunan seluas 1.000 ha. Jika dilihat dari hasil panen pada padi sawah, hasil per hektar dan produksinya, kecamatan lawang memiliki luas panen 1.876 ha. Selain itu hasil per hektarnya yaitu 75,74 dan produksinya mencapai 14.209 ton. Untuk hasil padi ladang, kecamatan lawang memiliki luas panen 47 ha, dengan hasil per hektarnya 261,64 dan produksinya mencapai 1.230 ton.

Selain itu, kecamatan selanjutnya yaitu boyolali. Kecamatan boyolali memiliki luas lahan 2,625,10000 dengan penggunaan sawah 294,6000 dan tanah kering 2,330,5000. Luas panen dari padi sawah yaitu 552 ha, rata-rata produksi 53,53, dan produksinya 2.955 ton. Untuk luas panen seluas 40 ha, rata-rata prduksi 50,00, dan produksi nya 200 ton.

\section{Perkembangan Sistem Pertanian Organik di Kampung Naga, Desa Neglasari, Kecamatan Salawu, Kabupaten Tasikmalaya}

Gapoktan Simpatik beranggotakan 11 kelompok tani yang tersebar di 4 kecamatan yang berada di lingkup Kabupaten Tasikmalaya (Tabel 3). Salah satu anggota kelompok tani berada di Kampung Naga, Desa Neglasari, Kecamatan Salawu, Kabupaten Tasikmalaya yaitu Kelompok Tani Serbaguna 2. Kelompok tani tersebut memiliki jumlah anggota petani organic terbanyak dibandingkan dengan kelompok tani lainnya. Pak Ucu merupakan ketua kelompok dan Pak Iin sebagai sekretaris kelompok. Masalah yang ada dalam kelompok tani ini adalah dalam administrasi. Menurut Ucu, masyarakat adat tidak biasa membuat catatan dari hasil maupun waktu tanam padi, sedangkan mereka dituntut oleh pemerintah, dan gapoktan simpatik untuk tertib administrasi. Sehingga masyarakat merasa ribet dan terbebani. Selain itu, padi disini pernah disertifikasi oleh ICS dan saat ingin diperpanjang sertifikasinya, Ucu menolaknya karena masyarakatnya malas mencatat. Sehingga apabila ada sertifikasi, pengurus kelompok tani yang harus mencatat semuanya. Terkadang pengurus merasa tidak enak karena harus menulis tata cara tani anggota tani walaupun semuanya sama. Kemudian saat ada infeksi harus ada tanda tangan pemiliknya sehingga tanda tandannya tidak asli.

Tabel 4. Data Kelompok Tani Anggota Gabungan Kelompok Tani Simpatik Kabupaten Tasikmalaya

\begin{tabular}{|c|c|c|c|c|c|c|}
\hline No & Kecamatan & Desa & $\begin{array}{l}\text { Kelompok } \\
\text { Tani }\end{array}$ & $\begin{array}{l}\text { Jumlah } \\
\text { Anggota }\end{array}$ & $\begin{array}{l}\text { Luas } \\
\text { Lahan }\end{array}$ & Ket \\
\hline 1 & Manonjaya & $\begin{array}{l}\text { Pasir Panjang } \\
\text { Margahayu } \\
\text { Margahayu }\end{array}$ & $\begin{array}{l}\text { Remaja I } \\
\text { Jembar } 2 \\
\text { Jembar Karya }\end{array}$ & $\begin{array}{l}39 \\
33 \\
15\end{array}$ & $\begin{array}{l}8.6 \\
6.0 \\
3.8\end{array}$ & \\
\hline 2 & Sukahening & $\begin{array}{l}\text { Pasir Batang } \\
\text { Kiara Jangkung }\end{array}$ & $\begin{array}{l}\text { Mekar Karya } \\
\text { Srilangen } 2\end{array}$ & $\begin{array}{l}48 \\
60\end{array}$ & $\begin{array}{r}7.2 \\
12.4\end{array}$ & \\
\hline 3 & Salawu & $\begin{array}{l}\text { Sunda Kerta } \\
\text { Sundawenang } \\
\text { Neglasari } \\
\text { Neglasari }\end{array}$ & $\begin{array}{l}\text { Mekarjaya } \\
\text { Sunda Mekar } \\
\text { Rancage } \\
\text { Serbaguna } 2\end{array}$ & $\begin{array}{l}21 \\
82 \\
79 \\
92\end{array}$ & $\begin{array}{l}6.0 \\
10.5 \\
15.1 \\
19.1\end{array}$ & \\
\hline & & Kawung Sari & $\begin{array}{l}\text { Sangkan } \\
\text { Hurin }\end{array}$ & 21 & 6.1 & \\
\hline 4 & Cisayong & Mekarwangi & Cidahu & $\frac{29}{519}$ & $\frac{16.3}{111}$ & \\
\hline
\end{tabular}


Menurut Pak Ucu, Gapoktan menyarankan bahwa yang penting ada tulisannya, tidak menghiraukan keadaan di lapangnya. Pengurus tidak enak karena seolah mereka yang bertanggung jawab telah berbohong meskipun mereka telah mendapatkan kepercayaan disini.

Respon dari Gapoktan atas penolakan Pak Ucu terhadap perpanjangan dari sertifikasi adalah mereka sangat kecewa. Walaupun mereka telah mengeluarkan biaya dan mengaharapkan untuk disertifikasi, meskipun hasilnya tidak dijual ke gapoktan. Jadi, masyarakat ingin memiliki brand sendiri bahwa kampung naga adalah benar-benar organik. Sedangkan secara administrasi tidak dapat dijalankan oleh masyarakat. Pendidikan anggota kelompok tani pun SD, bahkan ada yang tidak bisa menulis. Mereka menolaknya karena alasannya karena tidak enak segalanya sudah dibiayai oleh simpatik seperti pelatihan, tetapi dari mereka tidak ada timbal baliknya dengan menjual padinya. Masyarakat disini punya pasar sendiri, dan tidak memiliki orientasi bisnis atau menjualnya karena untuk konsumsi. Kemudian ketika ada yang mengontrol telah menjual seberapa kuintal, padahal nyatanya tidak. Hal tersebut terjadi karena di catatannya mereka menjual padinya ke gapoktan tersebut. Itulah yang membuat pengurus merasa terbebani. Selain itu disini juga pernah disertifikasi oleh IMO.

Selain itu, menurut Ucu, tidak ada perbedaan antara mendapatkan sertifikasi maupun tidak. Hal tersebut terjadi karena masyarakat luar sudah percaya bahwa di kampung ini sudah organik dari jaman dulu walaupun tidak disertifikasi. Kemarin saat mendapat sertifikasi pun tidak ada pengaruhnya karena organik sudah dilakukan secara turun menurun. Pemasarannya juga hanya dilakukan disini, seperti saat pengunjung yang datang. Dulu pernah ada orang korea yang tinggal di jakarta rutin membeli beras organik 1 kuintal per bulannya, tapi sekarang tidak lagi. Untuk satu orang pembeli yang membelinya di kampung ini, rata-rata membelinya $3 \mathrm{~kg}$, dan biasanya hanya untuk oleholeh. Harga beras organik berkisar Rp 20.000, beras merah juga $\mathrm{Rp}$ 20.000, sedangkan beras hitam lebih mahal yaitu Rp 22.000. Disini juga tidak semua organik/semi organik. Mereka masih khawatir untuk menggunakan pupuk urea, sedangkan perlakuannya masih sama dengan organik. Ketika ke sawahpun mereka juga masih membawa abu dan sisa makanan. Abu mereka gunakan untuk menghindari penyakit padi.

Tahun 2010-2012 masih banyak yang organik karena dapat support dari pemerintah seperti pupuk dan pelatihan sehingga semangatnya bangkit. Setelah itu, mereka ada yang tetap dengan organik, tetapi ada juga yang menjadi semi organik. Sampai dengan saat ini yang masih mempertahankan menanam padi organik hanya mencapai 10 orang. Kebanyakan yang menanamnya campur. Misalnya 1 petak ditanam organik, sisanya semi organik. Biasanya mereka menaman padi yang organik diletakkan paling atas dalam terasering agar tidak terkontaminasi yang konvensional. Ucu kurang lebih memiliki 75 bata dan semuanya ditanam organik, dan tambah lagi ada 60 bata.

Kesulitan dalam menanam organik adalah harus menjiwai dan dengan perasaan. Jika sudah cinta organik tidak akan ada komplain karena terdapat keikhlasan. Kendalanya dalam konversi itu harus banyak pupuknya. Untuk mengangkut pupuk mereka keberatan karena urea biasanya sedikit. Padahal mereka tidak melihat jika sudah melewati masa konversi, justru yang organik hanya membutuhkan sedikit pupuk. Ucu merasakan bahwa organik itu bagus. Menurutnya jika konvensional itu ketergantungan, karena jika tidak diberi pupuk maka padinya tidak akan tumbuh. Sedangkan jika organik, jika tidak diberi pupuk akan tumbuh, hanya pemeliharaannya saja. Pemeliharaannya memang lebih intensif dari konvensional, seperti penyiangannya karena organik lebih sering tumbuh rumput. Untuk jenis padi disini juga bervariasi.

Anggota kelompok tani ini terdapat 38 orang. Anggota kelompoknya ini tidak semuanya menanam organik, melainkan campuran. Anggota ini merupakan anggota yang sudah punya niat untuk menuju organik 100\%. Pemasaran disini juga bebas, seperti saat numbuk padi atau yang ada di rumahnya. Kelebihan dari organik menurut ucu adalah dari harganya. Untuk organik harganya Rp 20.000, sedangkan yang konvensional Rp 10.000, dan yang semi organik Rp 15.000. Jika dari produktifitas, per batanya lebih banyaknya tergantung pemeliharaan dan luas lahan. Tetapi jika dibandingkan dengan orang lain, menurut ucu organiknya lebih banyak. Ia pernah mendapatkan 1 bata mencapai 14 kilo. Jika yang konvensional rata-rata hanya $5-7$ kilo.

Peranan kelompok terhadap anggota adalah jika ada bantuan atau pelatihan yang diutamakan merupakan dari kelompok. Selain itu, untuk mendapatkan pupuk, anggota kelompok juga lebih mudah. Kalau untuk pemasaran tidak ada perbedaan. Untuk organik yang penting itu tanahnya. Untuk saat ini, penyuluhan tidak ada. Hanya saat ada proyek saja datang ke petani. Orang adat yang idealis tidak suka karena saat dibutuhkan tidak ada. Saat sebelum proyek jadi, penyuluh rajin datang, tetapi saat proyeknya jadi, tidak pernah di monitoring lagi.

Prediksi mengenai organik kedepannya akan berkembang tetapi secara independen karena disini tidak lagi menerima bantuan jika hanya menjadi beban masyarakat terutama dalam pelaporannya. Membuat laporan juga harus sesuai dengan RDKK, itu pun mereka tidak setuju karena mereka inginnya seadanya karena realitanya tidak seperti itu. Mereka inginnya benar-benar hanya bertani, sedangkan yang mencatatnya merupakan tugas PPL. Hal yang dicatat seperti tanggal mereka mencangkul, orang yang dilibatkan, penaburan, biaya yang dikeluarkan, dan segala perlakuan lainnya harus dicatat dari awal tanam hingga panen.

Padi disini merupakan padi 6 bulan, atau yang biasa disebut musim tanamnya Jan-Li, Januari-Juli. Perubahan iklim berpengaruh, karena musim tanamnya menjadi Juni akhir sehingga bukan Jan-Li lagi. Orang tua jaman dulu saat menentukan musim tanam Jan-Li juga sudah melalui percobaan dan pengalamannya. Hal tersebut terjadi karena untuk menghindari hama. Seperti kungkang, ia menyerang biasanya dalam waktu 2 minggu. Jadi saat musim kungkang, kalau bisa padi harus sudah mulai menguning. Musim tikus biasanya bulan agustus dan februari, kalau sudah gelap akan rusak padinya. Kalau tanamnya juli, padinya masih kecil jadi masih terang sehingga tidak ada tikus.

Bibit padi disini juga diambil dari swah sendiri. Setelah upacara panen, sebelum orang lain memanen, yang punya dulu mengambil benih atau biasa disebut ngawean. Bibit nya disimpan dulu untuk satu musim, dna digunakan dalam selang 1 kali panen. Pendatang mulai datang dan membeli organik semenjak booming tentang organik di Tasik yaitu tahun 2003, tetapi masyarakat disini baru mulai menjualnya pada tahun 2007. 
Untuk pupuk organik sendiri, biasanya adalah dari abu, selain itu merupakan dari kotoran ternak seperti kambing, domba, kelinci, dan marmut. Disamping itu juga ada kompos dari tumbuh tumbuhan seperti pisang, dan jerami. Disini sudah tradisi bahwa jerami tidak boleh dibakar. Jerami yang dibakar unsur haranya sudah tidak ada lagi menurutnya. Untuk menghancurkannya mereka membuat sendiri mol. Mereka diajarin untuk membuatnya. Membuatnya dari air beras, limbah dapur, kemudian pakai cuka aren. Satu meter persegi biasanya membutuhkan 1 kilo pupuk saat masa konversi. Akan tetapi kedepannya akan terus berkurang.

\section{Perkembangan Sistem Pertanian Organik di Kabupaten Boyolali}

Pada tahun 2016, Kabupaten Boyolali memiliki dua puluh kelompok tani yang sudah sertifikasi nasional bahkan empat diantaranya sudah sertifikasi internasional. Dua puluh kelompok tani tersebut terbagi menjadi tiga organisasi petani atau gabungan kelompok tani diantaranya Appoli, P3LL, dan APOB. Organisasi Appoli merupakan satu-satunya organisasi yang bergerak di sektor padi organik sedangkan dua organisasi lainnya bergerak di sektor padi non organik. Berikut ini nama kelompok tani yang tergabung dalam oganisasi Appoli.

Aliansi Petani Padi Organik Boyolali (Appoli) berdiri pada tahun 2007 dan sudah berbadan hukum pada tahun 2010. Ketua atau Direktur dari organisasi Appoli adalah Bapak Susatyo. Awal mula padi organik di Kabupaten Boyolali adalah adanya sosialisasi dari dinas pertanian setempat. Dinas pertanian melakukan survey ke lokasi dan terpilih 12 kelompok tani yang memenuhi syarat untuk menanam padi organik. Kelompok tani terpilih kemudian membentuk organisasi Appoli untuk memudahkan koordinasi dan pemasaran padi organik.

Organisasi ini bekerjasama dengan LSM internasional Veco yang membantu kelompok tani organik untuk memperoleh sertifikat internasional. Salah satu syarat memperoleh sertifikat internasional adalah kondisi lahan sawah tidak di lereng atau di bukit. Tahun 2016 ini, kerjasama keduanya berakhir dan saat ini tengah dilakukan perpanjangan kontrak kerjasama. Selain dengan Veco, organisasi ini juga bekerjasama dengan Argitera dan lembaga sertifikasi nasional (SNI).

Dalam hal pemasaran, Appoli bekerjasama dengan UD Tama Jaya Yogyakarta, PT BNS Jakarta, dan CV CSA Boyolali. Mekanisme pemasaran, masing-masing kelompok tani mengirimkan hasil padi organik ke organisasi Appoli dari organisasi langsung didistribusikan ke perusahaan pembeli. Sejauh ini, tidak semua hasil padi organik dijual ke Appoli namun 30 persen dari hasil produksi disimpan untuk memenuhi kebutuhan sendiri. Selain untuk keperluan sendiri, mereka juga membagikannya kepada tetangga. Semenjak memproduksi padi organik, mereka hampir tidak pernah mengkonsumsi padi non organik.

Berdasarkan informasi yang diperoleh dari anggota kelompok tani, padi organik dijual seharga Rp. $4.500 / \mathrm{kg}$ ke organisasi. Harga tersebut sudah menguntungkan menurut mereka. Selain menguntungkan, produksi padi organik tergolong murah dan ramah lingkungan. Petani padi organik wajib mengikuti prosedur penanaman padi organik yang merupakan hasil kesepakatan dari anggota organisasi. Hal tersebut menjadi syarat kelompok tani untuk memperoleh SNI.

Dalam satu kali panen mereka bisa memperoleh keuntungan bersih sebesar Rp. 7.000.000. Mereka juga membuat pupuk organik sendiri. Bahkan diantara mereka juga ada yang pernah memberikan penyuluhan pembuatan pupuk organik. Beberapa waktu yang lalu mereka juga sempat mengikuti sekolah lapang yang diadakan oleh dinas pertanian setempat. Pengairan berasal dari irigasi yang diambil dari sungai setempat. Sejauh ini petani tidak pernah kesulitan memperoleh air. Adapun masalah yang sering timbul hanya adanya hama.

Tabel 5. Kelompok tani yang tergabung dengan Appoli 2016

\begin{tabular}{|c|c|c|c|c|c|c|}
\hline No. & $\begin{array}{c}\text { Nama Kelompok } \\
\text { Tani }\end{array}$ & Alamat & Ketua & $\begin{array}{l}\text { Luas } \\
\text { (Ha) }\end{array}$ & Sumber Modal & Keterangan \\
\hline 1 & Pangudi Bogo & Dlingo, Mojosongo & Harjo & 24,87 & Swadaya & SNI \\
\hline 2 & Pangudi Raharjo & Dlingo, Mojosongo & $\begin{array}{l}\text { Dwijo } \\
\text { Martono }\end{array}$ & 16,46 & Swadaya & SNI \\
\hline 3 & Budi Rahayu & Catur, Sambi & $\begin{array}{l}\text { Trubus } \\
\text { Jatmiko }\end{array}$ & 18,03 & Swadaya & SNI \\
\hline 4 & Rukun Tani & Metuk, Mojosongo & Sastro Sinu & 28,60 & $\begin{array}{l}\text { APBD Provinsi/ } \\
\text { APBN }\end{array}$ & Internasional \\
\hline 5 & Ngudi Rejeki & Jatisari, Sambi & Walidi & 20,10 & Swadaya & SNI \\
\hline 6 & Sido Mulyo & Jatisari, Sambi & Bisri & 22,00 & Swadaya & SNI \\
\hline 7 & Lestari Makmur & Andong, Andong & Hambali & 13,50 & APBD Provinsi/ & Internasional \\
\hline 8 & Bina Lingkungan & Andong, Andong & Sarmin & 14,50 & $\begin{array}{l}\text { APBD Provinsi/ } \\
\text { APBN }\end{array}$ & Internasional \\
\hline 9 & Unggul Jaya & $\begin{array}{l}\text { Glonggong, } \\
\text { Nogosari }\end{array}$ & Sawal & 8,20 & $\begin{array}{l}\text { APBD Provinsi/ } \\
\text { APBN }\end{array}$ & Internasional \\
\hline 10 & Sari Mulyo & Wates, Simo & Rebin & 3,95 & Swadaya & SNI \\
\hline 11 & Kismo Luhur & Jatisari, Sambi & Sarjono & 8,00 & Swadaya & SNI \\
\hline 12 & Sido Tentrem & Jatisari, Sambi & Aliman & 11,00 & Swadaya & SNI \\
\hline
\end{tabular}




\section{Perkembangan Sistem Pertanian Organik di Desa Sumber Ngepoh, Kecamatan Lawang, Kabupaten Malang}

Gagasan melaksanakan pertanian organik dan berdirinya Kelompok Tani Sumber Makmur pada Tahun 1998 di Desa Sumber Ngepoh karena "kepepet" dengan terjadinya krisis ekonomi. Krisis ekonomi menyebabkan sarana produksi pertanian tidak tersedia, kelembagaan koperasi tidak berfungsi, dan insentif produksi pertanian bagi petani juga tidak tersedia. Suroto, berlima, dengan empat rekannya di desa nekat bercocoktanam padi tanpa menggunakan sarana produksi (pupuk dan obat-obatan kimia atau sarana produksi anorganik). Hasilnya, "hancur lebur", gagal total. Kemudian mereka mendatangi para sesepuh warga desa (orangrtua desa) untuk mengetahui bagaimana cara para sesepuh dahulu bercocok-tanam padi tanpa menggunakan pupuk dan obat-obatan kimia, yaitu sarana produksi yang digunakan ketika zaman pemerintahan Soeharto, Orde Baru. Pengetahuan dari para sesepuh desa kemudian mereka terapkan, tahun ke-3 bercocok-tanam padi tanpa menggunakan pupuk dan obat-obatan kimia, dan dengan sumber air untuk pengairan sawah mereka bersumber dari mata air tidak "bercampur" dengan aliran irigasi pertanian lainnya yang menggunakan pupuk dan obat-obatan kimia, mulai memberikan hasil. Selama hampir tiga musim kehidupan keluarga "morat-marit" karena tanpa hasil produksi pertanian. Di dalam keluarga, mereka berlima, sering terjadi konflik dengan isteri, karena "mendapat dampratan $5 \mathrm{~cm}$ di depan wajah" berupa kemarahan karena tanpa penghasilan produksi pertanian. Sejak itu, mulai dibentuk Kelompok Tani Sumber Makmur dengan fokus bercocoktanam padi organik.

Kelompok Tani Sumber Makmur berkembang hingga saat ini dengan jumlah anggota kelompok tani sebanyak 2106 orang dan luas lahan pertanian padi organik $25 \mathrm{Ha}$. Pak Suroto sampai sekarang menjadi Ketua Kelompok Tani Sumber Makmur-1, karena dalam perkembangannya terbentuk Kelompok Tani Sumber Makmur-2 dengan luas lahan sekitar $40 \mathrm{Ha}$, dan Kelompok Tani Sumber Makmur-3 dengan luas lahan sekitar 10 Ha. Kemudian dibentuk Gabungan Kelompok Tani (Gapoktan) Sumber Mulyo yang menjadi "payung" tiga kelompok tani tersebut. Perkembangan pertanian organik, kelompok tani dan gapoktan, dan dinamika dalam kehidupan struktur sosial masyarakar Desa Sumber Ngepoh terkait dengankondisi Desa Sumber Ngepoh sebelumnya yang termasuk dan dikategorikan sebagai Desa IDT.

Produksi padi organik anggota Kelompok Tani Sumber Makmur-1 rata-rata 9 ton per Ha. Dari sisi budidaya pertanian organik di desa ini didukung dengan empat sumber mata air yang mengairi produksi pertanian padi sawah di desa ini, yaitu: (1) Mata Air Towo; (2) Mata Air Krabyaan; (3) Mata Air Gondang; dan (4) Mata Air Pasu. Kesepakatan anggota kelompok tani: sebanyak 30 Persen dikonsumsi anggota dan 70 Persen dibisniskan untuk pendapatan kelompok tani dan anggota kelompok tani. Produksi padi organik dikelola oleh kelompok tani sebagai usaha bersama dan di aras Gapoktan dikenal sebagai Asosiasi Usaha Bersama Pertanian Organik, yang masih berfokus pada padi dan beras organik. Asosiasi usaha bersama yang mengolah gabah yang disimpan kelompok menjadi beras organik dari penggilingan padi milik anggota kelompok yang ikatan kerajasamanya dituangkan dalam suatu kontrak setiap musimnya. Anggota kelompok melakukan "packaging" beras organik dalam satuan $25 \mathrm{Kg}$ dan $5 \mathrm{Kg}$. Selain itu juga dilakukan "packaging" dalam satuan $1 \mathrm{Kg}$ untuk beras hitam dan beras merah organik. Pemasaran produk beras organik masih mengandalkan pada "pemesanan" konsumen secara perorangan, pedagang, dan pihak-pihak secara kelembagaan seperti dari kantor dan pebisnis, seperti pengusaha bubur beras organik. Belum ada pemasaran yang lebih pro-aktif, karena mereka belum mampu menjamin kuantitas dan kualitas yang dibutuhkan konsumen. Meskipun demikian, kelompok tani pertanian organik ini telah mendapatkan sertifikasi, dan yang disertifikasi organik adalah lahan pertaniannya. Dengan sertifikasi ini semua komoditas pertanian yang dihasilkan di atas lahan pertanian organik dikategorikan produk pertanian organik. Pertanian organik di Desa Sumber Ngepoh telah disertifikasi oleh dua lembaga sertifikasi pertanian organik.

Perkembangan usaha pertanian organik yang dilakukan Kelompok Tani Sumber Makmur-1 tidak hanya di sektor onfarm, tetapi juga mulai berkembang di sektor off-farm, yakni yang telah dilakukan adalah pemanfaatn "beras patah" menjadi "selarial" dalam yang dikemas dalam botol, lengkap dengan petunjuk, komposisi, dan trade mark produksi selarial. Belum ada upaya lain untuk mengembangkan sektor off-farma dari beras organik. Belum ada upaya-upaya pengembangan sektor non-farm yang masih terkait dengan on-farm dan off-farm dari pertanian organik, khususnya padi dan beras organik.

Perkembangan non-farm di Desa Sumber Ngepoh adalah industri rumahtangga pembuatan suttle cock. Sebanyak 40 Persen rumahtangga di desa ini, selain berusaha dalam bidang pertanian, baik pertanian organik maupun semi-organik, mereka, khususnya ibu-ibu rumahtangga melakukan produksi suttle cock tersebut, yang dalam istilah warga Desa Sumber Ngepoh disebut "nancep bulu". Dimulai 3 dengan warga desa ini bekerja di pabrik pembuatan suttle cock, kemudian mereka malkukan usaha sendiri di desa. Paling tidak ada tiga industri rumahtangga yang telah berkembang menjadi industri kecil suttle cock, dengan karakteristik ada bangunan untuk industri dan memperkerjakan sampai 60 tenaga kerja, diantaranya banyak dilakukan tidak hanya ibu rumahtangga tetapi juga tenaga kerja anak. Ibuibu rumahtangga, selain bekerja di rumah industri kecil, mereka selalu membawa pekerjaan membuat suttle cock tersebut menjadi pekerjaan sambilan di rumahtangganya. Menurut Pak Suroto, industri rumahtangga ini dalam sepuluhlima belas tahun terakhir ini secara signifikan telah meningkatkan kesejahteraan masyarakat Desa Sumber Ngepoh. Bahkan bagi para tenaga kerja anak, kerja sambilan ini mampu memenuhi kebutuhan konsumtif mereka, juga sampai mampu mengambil kredit sepeda motor. Dari sisi pendapatan, dengan adanya industri rumah tanggak pembuatan suttle cocok melengkapi pola pendapatan masyarakat desa ini, selain memiliki pendapatan musimam tiga bulanan melalui pendapatan dari produksi petanian organik, mereka juga memiliki pola pendapatan mingguan dari bekerja dalam pembuatan suttle cock yang dapat memenuhi pendapatan cash untuk kebutuhan sehari-hari. Akan tetapi dari sisi yang lain, timbul persaingan dalam kebutuhan tenaga kerja. Semakin sulit mendapatkan tenaga kerja untuk produksi pertanian organik, karena kaum ibu rumahtangga dan perempuan cenderung memilih bekerja di industri rumahtangga pembuatan suttle cock dari padi bekerja di sektor on-farm dan off-farm pertanian organik.

Menurut informan, terdapat usaha sektor non-farm yang sangat potensial dikembangkan di Desa Sumber Ngepoh, yakni pariwisata sumber Mata Air Krabyakan yang juga potensial dikembangkan terkait dengan usaha sektor onfarm dan off- 
farm pertanian organik. Akan tetapi pengembangan potensi pariwisata tersebut memelukan $15 \mathrm{Ha}$ lahan, dan lahan yang potensial di sekitar obyek wisata tersebut adalah aktualnya lahan pertanian organik.

Dalam kelembagaan pemerintahan desa Sumber Ngepoh, menurut informan "tidak mendukung" dan "tidak penah memberikan penghargaan" kepada para petani yang melaksanakan pertanian organik di Desa Ngepoh. Kelembagaan BUMDES Sumber Ngepoh sudah terbentuk, tetapi menurut informan tidak ada keterkaitan dengan kelembagaan pertanian organik.

\section{Hasil Uji Distribusi Frekuensi}

\section{Karakteristik Petani (x.2)}

Pada karakteristik petani, tingkat pendidikan formal yang dominan ditempuh oleh petani organik di ketiga daerah (Tasik, Malang, dan Boyolali) yaitu tamat SD sebesar 30\%, tamat SMP sebesar 30\%, dan tamat SMA sebesar 30\%. Selain menempuh pendidikan formal, beberapa petani organik pada tiga daerah tersebut juga menempuh pendidikan non formal yaitu sebanyak 30\% mengikuti pelatihan pembuatan peptisida nabati. Disamping bertani organik, petani tersebut juga menanam padi non-organik. Pengalaman petani menaman padi non-organik yaitu rata-rata selama 4-11 tahun sebanyak 30\%, dan 12-19 tahun sebanyak 30\%. Untuk pengalaman bertani padi organik, rata-rata memiliki pengalaman selama 9-11 tahun yaitu sebanyak 40\%. Selain itu, status dari keanggotaan kelompok tani beragam, baik hanya sebagai anggota maupun pengurus. Akan tetapi, sebanyak 70\% petani menjawab bahwa statusnya hanya anggota biasa dan aktif dalam kelompok tersebut.

\section{Prosedur Operasional Standar (SOP) (x.8)}

Pada setiap SOP, hampir semua dari prosedur diterapkan, akan tetapi untuk menekan/ menghilangkan penyakit $60 \%$ menjawab bahwa diterapkan, $80 \%$ menjawab diterapkan pada hal pembajakan, $90 \%$ menerapkan memudahkan pengaturan air, $60 \%$ menerapkan untuk membuat kakalen, $60 \%$ menerapkan kultur kimia dengan peptisida, $70 \%$ menerapkan untuk memakai alat perontok, dan menggunakan alas yang lebar.

\section{Deterioration (Kemerosotan) (x.7)}

Terkait upaya memelihara manfaat untuk memperpanjang sustain, untuk menjadi anggota kelompok tani, sebesar 100\% mereka menjawab selalu penting. Selain itu, menurut mereka $90 \%$ menjawab selalu ingin kelomok tani organik ini terus berjalan. Sebanyak 70\% mereka juga mengakui bahwa selalu terus aktif dalam kegiatan kelompok tani. Jika ada permasalahan yang muncul dalam kelompok, sebanyak 60\% mereka menyatakan bahwa akan menyelesaikan masalah tersebut. Selain itu mereka juga memperoleh manfaat dari bertani padi organik. Hasil panen, pendapatan, dan harga lebih tinggi dari padi non organik menurut mereka juga selalu meningkat yang diakui sebesar $80 \%$. Mereka juga memperoleh manfaat sosial dari bertani padi organik yang diakui sebanyak $60 \%$. Menurut mereka yaitu sebesar 05 menjawab bahwa kelompok tani lebih aktif. Dalam mendapatkan kunjungan dari dinas atau pemerintah daerah menurut mereka tidak pernah yaitu sebesar 40\%. Mereka juga mengakui bahwa sebesar $70 \%$ bahwa sering ada pembeli lain dari luar Gapoktan. Selain itu, mereka mengakui bahwa mereka sering diundang pertemuan oleh gapoktan untuk membahas kelompok, dan sering diundang pelatihan terkait dengan pengembangan sistem pertanian organik. Sebanyak $70 \%$ mereka mengakui bahwa mereka tidak pernah diundang oleh pihak lain selain Gapoktan, apalagi dikunjungi oleh bupati. Pemerintah desa menurut mereka selalu mendukung kegiatan pertanian organik. Disamping itu mereka juga memperoleh manfaat lingkungan dari bertani organik, kualitas tanaman meningkat, tanah semakin subur, tanah semakin subur, tanah semakin mudah diolah yaitu sebesar $100 \%$.

Mengenai radius pihak-pihak yang terlibat dengan kelompok tani, radius ke petani itu senduru yaitu sangat dekat yang dijawab dengan persentase $100 \%$, ketua kelompok tani persentase $90 \%$, prngurus gapoktan $90 \%$, pengurus gapoktan $80 \%$, PPL memiliki persentase $50 \%$ sangat dekat, tokoh masyarakat memiliki radius dekat dengan persentase $70 \%$, pemilik ternak yang menjual kotoran dekat dengan persentase $80 \%$, Penjual pupuk kompos sebesar $60 \%$ dengan radius sangat dekat, dan tetangga persentase $70 \%$ sangat dekat. Sebanyak $50 \%$ merasa jauh dengan kelompok lain dalam satu gapoktan, 50\% merasa jauh dengan kelompok lain diluar gapoktan, 100\% merasa dekat dengan pasar, $80 \%$ merasa jauh dari penggilingan, $100 \%$ merasa jauh dari bank, $100 \%$ merasa jauh dari lembga sertifikasi nasional, $80 \%$ merasa jauh dari lembaga sertifikasi internasional, $80 \%$ merasa jauh dari $\mathrm{CV}, 90 \%$ merasa jauh dari pembeli dalam negeri, $40 \%$ merasa jaug dari lembaga luar negeri, $60 \%$ merasa jauh dari pembeli luar desa, $80 \%$ merasa jauh dari ketua gapoktan, 60\% merasa dekat dengan dekat dengan ketua $\mathrm{CV}, 50 \%$ mersa dekat dengan operator mesin traktor, $80 \%$ merasa dekat dengan pemerintah pusat, $80 \%$ merasa sangat dekat dengan pemilik alat transportasi hasil pertanian, 70\% merasa sangat dekat dengan keluarga, 60\% merasa jauh dari suami/istri, 70\% merasa dekat dengan koperasi, 60\% merasa sangat jauh dengan buruh tani. Mereka juga tidak pernah kenal dengan tamu dari luar negeri yang pernah berkunjung ke gapoktan yaitu sebesar $80 \%, 60 \%$ mereka tidak pernah kenal dengan pejabat pemerintah pusat, dan $100 \%$ merasa tidak pernah kenal dengan pejabat kabupaten, 90\% mereka merasa tidak pernah bersaing dengan teman sekelompok mereka, 100\% merasa sering merasa bersaing dengan kelompok tani lain, 60\% merasa sering memiliki keterbukaan gapoktan dalam mengelola penjualan beras organik, 40\% merasa selalu menyampaikan ketidaksetujuan mereka terhadap gapoktan, 60\% merasa selalu berdebat dalam menentukan harga, $80 \%$ selalu merasa gapoktan menentukan harga jual gabah kering giling, 70\% merasa selalu menjalai sertifikasi nasional, $70 \%$ merasa tidak pernah menjalani sertifikasi internasional, $80 \%$ merasa sering bahwa sakah satu anggota kelompok mendominasi keputusan, $60 \%$ merasa sering salah satu anggota gapoktan merasa mendominasi keputusan.90\% merasa kadang-kadang keaktifan anggota kelompok, 100\% merasa tidak pernah musim kering yang panjang, 100\% tidak pernah kesulitan bibit unggul, 90\% merasa tidak pernah mencari bahan alami untuk buat pupuk kompos, $100 \%$ tidak pernah merasa tidak pernah kurang ternak untuk dimanfatkan kotorannya, 100\% tidak pernah kurang sumber permodalan, 90\% tidak pernah kesulitan buat peptisida nabati, 90\% tidak sulit menyuburkan tanah, 90\% tidak pernah sulit mengetahui mikroorganisme dalam tanah, 100\% tidak pernah sulit membuat filter air, 70\% sering sumber air yang mengairi lahan padi organik terkontaminasi bahan kimia, 70\% tidak pernah ktidaksesuaian harga, $80 \%$ sering kesulitan cari pembeli lain selain gapoktan, $60 \%$ sering harga beras organik relatif mahal, $60 \%$ sering pemerintah memberikan bantuan 
ternak untuk pupuk organik, dan $60 \%$ sering gapoktan memiliki ternak bersama yang mnegasilkan pupuk kompos.

\section{Persepsi tentang ciri-ciri inovasi (x.6)}

Terkait dengan tingkat keuntungan relatif, dalam menerapkan pertanian organik menurut mereka mnguntungkan yaitu sebesar $60 \%$. Selain itu, untuk menerapkan pertanian organik, menurtu mereka sesuai dengan kebutuhan yaitu sebesar $60 \%$. Untuk menerapkan pertanian organik, menurut mereka rumit dengan persentase $60 \%$. Dalam menerapkan pertanian organik, kemungkinan untuk dicoba yaitu memungkinkan untuk dicoba yaitu sebesar $60 \%$, dan untuk tingkat kemungkinan diamati, menurut mereka $60 \%$ memungkinkan untuk diamati.

\section{Konteks Kelembagaan (x.5)}

Untuk menjadi anggota kelompok tani dan menjadi anggota, mereka menjawab $100 \%$ tidak rumit. Selain itu untuk mengurus badan hukum kelompok tani, 70\% mereka menjawab cukup rumit, dan $100 \%$ menjawab tidak rumit untuk mengundang PPL untuk hadir diskusi kelompok, dan juga tidak rumit untuk mengundang Gapoktan untuk hadir ke diskusi kelompok. Untuk bertemu dengan ketua gapoktan, 40\% mereka mengakui bahwa cukup rumit dan tidak rumit. Untuk memiliki lahan garapan padi organik, petani menjawab 100\% tidak rumit. Selain itu untuk mengikuti sertifikasi nasional menurut mereka cukup rumit, dan tidak rumit mengikuti sertifikasi internasional sebanyak $50 \%$. Hal yang rumit dilakukan yaitu mengundang pimpinan $\mathrm{CV}$ untuk diskusi kelompok yang diakui memiliki persentase $80 \%$. Untuk mengundurkan diri dari keanggotaan kelompok tani dan gapoktan menurut mereka tidak rumit yaitu sebesar $100 \%$. Sedangkan untuk memperoleh bukti fotokopi sertifikasi nasional dari gapoktan yaitu sebesar 50\%. Untuk mengolah lahan padi organik, menurut mereka sebanyak $70 \%$ menjawab cukup rumit. Sedangkan untuk memperoleh bibit padi organik, membuat pupuk organik, membuat peptisida nabati, memperoleh traktor, memperoleh alat sarana pertanian, memperoleh alat transportasi hasil pertanian menurut mereka tidak rumit yaitu sebesar $100 \%$. Selain itu, menurut mereka tidak rumit memperoleh modal bertani organik, dan juga tidak ruumit untuk menjual hasil panennya.

\section{Indikator Keberlanjutan Kelembangaan (x.3)}

Pada variabel fakta, petani organik akan menggambarkan mengenai sikap terhadap informasi, komunikasi, pengambilan keputusan dan partisipasi . Pada pertemuan Gapoktan, presentasi kehadiran petani organik dalam pertemuan tersebut yaitu sebesar $70 \%$ atau disebut hanya kadang-kadang saja. Dalam pertemuan Gapoktan, rata-rata petani organik sering menyampaikan pendapatnya yaitu sebesar $80 \%$. Walaupun mereka menyampaikan pendapatnya dalam pertemuan Gapoktan, akan tetapi mereka tidak pernah mengambil keputusan dalam pertemuan tersebut yaitu $70 \%$ dari jawaban petani. Tetapi dari pendapat yang disampaikan oleh petani organik, sebanyak $80 \%$ pendapat mereka diterima oleh pengurus Gapoktan. Menurut petani organik, penyuluh selalu hadir dalam pertemuan kelompok yaitu sebesar $80 \%$. Akan tetapi pada pertemuan Gapoktan, penyuluh hanya sering hadir dalam pertemuan tersebut sehingga persentasenya lebih sedikit yaitu $60 \%$. Selain itu, rata-rata petani organik memiliki inisiatif sebanyak $80 \%$ atau termasuk sering dalam menyampaikan pendapatnya. Disamping sering menyampai pendapat, mereka juga berani menyampaikan pendapat secara langsung dalam rapat yaitu termasuk dalam kategori sering dan digambarkan dengan persentase 90\%. Untuk hasil dari kesepakatan kelompok, sebanyak $80 \%$ petani menjawab selalu, dan untuk hasil kesepakatan gapoktan sebanyak $80 \%$ dengan jawaban sering.

Selain itu, untuk melihat partisipasi mereka dalam Gapoktan, maka terlebih dahulu dilihat alasan mereka bergabung dan mengikuti pertemuan. Sebanyak $90 \%$ petani organik menjawab bahwa mereka bergabung di Gapoktan karena sesuai dengan kebutuhan. Selain itu mereka mengikuti Gapoktan kebanyakan karena mengikuti teman yaitu sebesar 50\%. Akan tetapi mereka ikut ke Gapoktan tidak karena terpaksa sehingga sebesar 100\% menjawab tidak. Mereka ikut dalam Gapoktan juga merasa karena memang sudah seharusnya menjadi anggota Gapoktan sehingga 90\% menjawab Ya. Disamping itu, untuk melihat alasan mereka tergabung dalam Gapoktan, sebanyak 90\% mereka menghadiri pertemuan karena ingin mendapat ilmu. Selain itu, sebanyak $100 \%$ petani organik menghadiri pertemuan bukan karena ingin mendapatkan uang transport, dan untuk mengikuti baik kelompok dan gapoktan tidak menjadi beban bagi mereka. Selain itu, penentu keputusan kegiatan kelompok tani yang menempati urutan pertama yaitu anggota kelompok tani itu sendiri, yaitu $100 \%$ dari jawaban.

Untuk melihat kinerja kelompok, sebanyak 100\% petani organik selalu ingin menerapkan sistem pertanian organik, dan menanam padi organik. Selain itu sebanyak $60 \%$ petani selalu menjual organik menjual padi yang mereka tanam ketika tidak punya uang. Ketika harga jual padi organik tinggi, petani akan menjual padi organiknya dan sebanyak $100 \%$ tidak pernah membeli padi non organik. Selain itu $90 \%$ petani tidak pernah menjual semua padinya. Sehingga selain menjual, mereka juga menyimpannya untuk dikonsumsi. Petani organik selalu melakukan sistem pertanian organik untuk memenuhi kehidupan mereka, yaitu sebesar 90\%, 100\% selalu sesuai dengan kemampuan mereka, dan $100 \%$ selalu menerapkan sistem pertanian organik karena sesuai dengan aturan kelompok tani. Walaupun juga selalu mengikuti sistem pertanian yang sesuai dengan aturan gapoktan, akan tetapi persentasenya lebih sedikit yaitu $90 \%$. Hal tersebut terjadi karena dalam menerapkan sistem tersebut sebesar $100 \%$ menguntungkan. Menurut jawaban petani organik, 80\% menjawab bahwa sistem tersebut tidak pernah menjadi kebiasaan dari leluhur. Mereka 100\% paham dalam bertani organik. Sebanyak $70 \%$ petani organik juga menjawab bahwa mereka selalu dengan kesepakatan kelompok, dan selalu memproduksi dengan kualitas yang sesuai dengan standar Gapoktan.

Pertanian organik sebanyak $90 \%$ selalu menjadi sumber nafkah utama, dan sering menjadi sumber pemasukan utama Gapoktan yaitu sebesar 50\%. Selain itu, bahan-bahan alami mudah diperoleh untuk membuat pupuk organik, yaitu $80 \%$ menjawab selalu. Untuk melihat kepercayaan mereka terhadap gapoktan, sebanyak $60 \%$ atau mereka sering percaya bahwa Gapoktan dapat mengelola penjualan padi organik hasil panen mereka, dan juga menjual padi organik ke Gapoktan merupakan hal yang utama. Masih sama halnya dengan hal sebelumnya, mereka medahulukan menjual padi mereka ke Gapoktan. Dalam menyepakati peraturan penjualan padi organik, petani menjawab sebanyak 50\% bahwa peraturan tersebut selalu disepakati antara petani anggota kelompok dan ketua kelompok. Hal tersebut juga terjadi dalam menyepakati peraturan penjualan antara petani 
anggota kelompok dan pengurus Gapoktan yaitu sebesar $60 \%$ menjawab sering. Untuk kesepakatan antara ketua kelompok dan pengurus Gapoktan kebanyakan mereka menjawab sering yaitu denga persentase $60 \%$. Mengenai harga jual padi organik, petani menjawab $60 \%$ sering bahwa harga tersebut disepakati antara ketua kelompok dna Gapoktan, serta jika dilihat dari pihak lain yaitu eksportir tidak pernah mendukung keberhasilan penjualan padi organik yaitu sebesar $60 \%$. Untuk urutan kepada pihak yang mnejadi tempat petani organik tersebut menjual padi organiknya, biasanya ke pasar. Selain itu biasanya mereka menjual ke Gapoktan dan pembeli dari luar.

Untuk aspek tata kelola, yang mencangkup pola-pola hubungan, transparasi, pembagian tanggung jawab, dan kerjasama, petani organik biasanya selalu memiliki cara tersendiri dalam menanam padi organik yaitu $50 \%$ dan $90 \%$ selalu mematuhi aturan Gapoktan. Disamping itu, walaupun mereka mengikuti aturan, akan tetapi mereka hampir 60\% menjawab bahawa tidak pernah memiliki fotokopi tata atura dalam menerapkan budidaya padi organik. Petani organik juga 90\% selalu menerapkan semua tata cara sistem pertanian organik, dan $60 \%$ menerapkan sebagai tata cara sistem pertanian organik. Selain itu, menurut $60 \%$ dari jawaban petani bahwa pihak Gapoktan melaporkan perkembangan penjualan padi organik, dan serupa dengan yang dilakukan oleh kelompok tani. Sebanyak 50\% petani menganggap bahwa kelompok tani mengetahui kendalakendala yang dihadapi oleh gapoktan. Petani organik sabanyak $60 \%$ mnegakui bahwa mereka tidak memiliki fotokopi bukti sertifikasi nasional, dam mereka juga tidak pernah memiliki laporan perkembangan penjualan dari pengurus Gapoktan. Sebanyak $80 \%$ mereka sering menjual padi organik kepada ketua kelompok untuk dijual ke Gapoktan, dan 80\% mengakui tidak pernah membeli padi organik kepada anggota kelompok. Selain itu, sebanyak $80 \%$ gapoktan simpatik menentukan tata cara menanam padi secara organik. Mereka juga mengakui bahwa sebesar $60 \%$ selalu membuat filter pada lahan padi organik mereka. Mengenai penggunaan pupuk kimia, mereka mengakui bahwa $90 \%$ tidak pernah menggunakan hal tersebut. Mereka juga tidak pernah menjual padi non organik ke Gapoktan Simpatik yaitu sebesar $50 \%$, dan selalu bersedia lahan organik mereka disertifikasi nasional dan internasional. Mereka juga 90\% tidak pernah menggunakan pupuk kimia.

\section{Indikator Keberlanjutan Kelembangaan (x.3)}

Padavariabelfakta, petaniorganikakanmenggambarkanmengenai sikap terhadap informasi, komunikasi, pengambilan keputusan dan partisipasi. Pada pertemuan Gapoktan, presentasi kehadiran petani organik dalam pertemuan tersebut yaitu sebesar $70 \%$ atau disebut hanya kadang-kadang saja. Dalam pertemuan Gapoktan, rata-rata petani organik sering menyampaikan pendapatnya yaitu sebesar $80 \%$. Walaupun mereka menyampaikan pendapatnya dalam pertemuan Gapoktan, akan tetapi mereka tidak pernah mengambil keputusan dalam pertemuan tersebut yaitu 70\% dari jawaban petani. Tetapi dari pendapat yang disampaikan oleh petani organik, sebanyak $80 \%$ pendapat mereka diterima oleh pengurus Gapoktan. Menurut petani organik, penyuluh selalu hadir dalam pertemuan kelompok yaitu sebesar $80 \%$. Akan tetapi pada pertemuan Gapoktan, penyuluh hanya sering hadir dalam pertemuan tersebut sehingga persentasenya lebih sedikit yaitu $60 \%$. Selain itu, rata-rata petani organik memiliki inisiatif sebanyak $80 \%$ atau termasuk sering dalam menyampaikan pendapatnya. Disamping sering menyampai pendapat, mereka juga berani menyampaikan pendapat secara langsung dalam rapat yaitu termasuk dalam kategori sering dan digambarkan dengan persentase 90\%. Untuk hasil dari kesepakatan kelompok, sebanyak $80 \%$ petani menjawab selalu, dan untuk hasil kesepakatan gapoktan sebanyak $80 \%$ dengan jawaban sering.

Selain itu, untuk melihat partisipasi mereka dalam Gapoktan, maka terlebih dahulu dilihat alasan mereka bergabung dan mengikuti pertemuan. Sebanyak $90 \%$ petani organik menjawab bahwa mereka bergabung di Gapoktan karena sesuai dengan kebutuhan. Selain itu mereka mengikuti Gapoktan kebanyakan karena mengikuti teman yaitu sebesar 50\%. Akan tetapi mereka ikut ke Gapoktan tidak karena terpaksa sehingga sebesar 100\% menjawab tidak. Mereka ikut dalam Gapoktan juga merasa karena memang sudah seharusnya menjadi anggota Gapoktan sehingga 90\% menjawab Ya. Disamping itu, untuk melihat alasan mereka tergabung dalam Gapoktan, sebanyak 90\% mereka menghadiri pertemuan karena ingin mendapat ilmu. Selain itu, sebanyak $100 \%$ petani organik menghadiri pertemuan bukan karena ingin mendapatkan uang transport, dan untuk mengikuti baik kelompok dan gapoktan tidak menjadi beban bagi mereka. Selain itu, penentu keputusan kegiatan kelompok tani yang menempati urutan pertama yaitu anggota kelompok tani itu sendiri, yaitu $100 \%$ dari jawaban.

Untuk melihat kinerja kelompok, sebanyak 100\% petani organik selalu ingin menerapkan sistem pertanian organik, dan menanam padi organik. Selain itu sebanyak $60 \%$ petani selalu menjual organik menjual padi yang mereka tanam ketika tidak punya uang. Ketika harga jual padi organik tinggi, petani akan menjual padi organiknya dan sebanyak $100 \%$ tidak pernah membeli padi non organik. Selain itu $90 \%$ petani tidak pernah menjual semua padinya. Sehingga selain menjual, mereka juga menyimpannya untuk dikonsumsi. Petani organik selalu melakukan sistem pertanian organik untuk memenuhi kehidupan mereka, yaitu sebesar 90\%, 100\% selalu sesuai dengan kemampuan mereka, dan $100 \%$ selalu menerapkan sistem pertanian organik karena sesuai dengan aturan kelompok tani. Walaupun juga selalu mengikuti sistem pertanian yang sesuai dengan aturan gapoktan, akan tetapi persentasenya lebih sedikit yaitu $90 \%$. Hal tersebut terjadi karena dalam menerapkan sistem tersebut sebesar $100 \%$ menguntungkan. Menurut jawaban petani organik, $80 \%$ menjawab bahwa sistem tersebut tidak pernah menjadi kebiasaan dari leluhur. Mereka 100\% paham dalam bertani organik. Sebanyak $70 \%$ petani organik juga menjawab bahwa mereka selalu dengan kesepakatan kelompok, dan selalu memproduksi dengan kualitas yang sesuai dengan standar Gapoktan.

Pertanian organik sebanyak $90 \%$ selalu menjadi sumber nafkah utama, dan sering menjadi sumber pemasukan utama Gapoktan yaitu sebesar 50\%. Selain itu, bahan-bahan alami mudah diperoleh untuk membuat pupuk organik, yaitu $80 \%$ menjawab selalu. Untuk melihat kepercayaan mereka terhadap gapoktan, sebanyak $60 \%$ atau mereka sering percaya bahwa Gapoktan dapat mengelola penjualan padi organik hasil panen mereka, dan juga menjual padi organik ke Gapoktan merupakan hal yang utama. Masih sama halnya dengan hal sebelumnya, mereka medahulukan menjual padi mereka ke Gapoktan. Dalam menyepakati peraturan penjualan padi organik, petani menjawab sebanyak 50\% bahwa peraturan tersebut selalu disepakati antara petani anggota kelompok dan ketua kelompok. Hal tersebut juga terjadi dalam menyepakati peraturan penjualan antara petani anggota kelompok dan pengurus Gapoktan yaitu sebesar $60 \%$ menjawab sering. Untuk kesepakatan antara ketua kelompok 
dan pengurus Gapoktan kebanyakan mereka menjawab sering yaitu denga persentase $60 \%$. Mengenai harga jual padi organik, petani menjawab $60 \%$ sering bahwa harga tersebut disepakati antara ketua kelompok dna Gapoktan, serta jika dilihat dari pihak lain yaitu eksportir tidak pernah mendukung keberhasilan penjualan padi organik yaitu sebesar $60 \%$. Untuk urutan kepada pihak yang mnejadi tempat petani organik tersebut menjual padi organiknya, biasanya ke pasar. Selain itu biasanya mereka menjual ke Gapoktan dan pembeli dari luar

Terkait dengan variabel ketahanan pangan rumah tangga, 90 persen responden memiliki frekuensi makan 3 kali sehari, 100 persen responden memiliki ketersedian beras. 60 persen responden memiliki jumlah pendapatan rata-rata dari hasil usahatani sebesar Rp 3.985.000. 30 persen responden memiliki jumlah pendapatan rata-rata dari hasil non usahatani sebesar Rp 730.000. 80 persen responden memiliki jumlah ratarata per bulan sebesar Rp 3.216.562,5. 50 persen responden memiliki jumlah rata-rata per tahun sebesar Rp 29.825.000. 100 persen istri responden tidak memiliki pendapatan baik dari hasil usahatani maupun dari hasil non usahatani karena tidak memiliki pekerjaan.

100 persen anak responden tidak memiliki pendapatan usaha tani dan non usaha tani. 10 persen anak resonden memiliki rata-rata jumlah pendapatan per bulan sebesar $\mathrm{Rp} 30.000$ tetapi tidak memiliki jumlah pendapatan per tahun. 60 persen responden memiliki akses lokasi pasar ke dalam desa. 100 responden memiliki akses jarak ke sumber pangan kurang dari $1 \mathrm{~km} .100$ persen responden memiliki akses dalam waktu perjalanan kurang dari 30 menit. 80 persen responden memiliki akses dalam biaya perjalanan kurang dari Rp 2.000. Ratarata responden memiliki akses terhadap beras/padi-padian \& turunannya sebesar Rp 4.599/kg. Rata-rata responden memiliki akses terhadap umbi-umbiannya\&turunannya sebesar Rp $1.200 / \mathrm{kg}$. rata-rata responden memiliki akses terhadap gula dan produk olahannya sebesar Rp 14.400/kg. rata-rata responden memiliki akses terhadap biji berminyak atau buah \& produk olahannya sebesar rp 1.200/kg. Rata-rata responden memiliki akses terhadap buah-buahan sebesar Rp 6800/kg. Rata-rata responden memiliki akses terhadap sayuran sebesar Rp 750/ $\mathrm{kg}$. Rata-rata responden memiliki akses terhadapdaging sebesar Rp 82.400/kg. Rata-rata responden memiliki akses terhadap telur sebesar Rp 30.900/kg. Rata-rata responden memiliki akses terhadap susu sebesar Rp 3.400/kg. Rata-rata responden memiliki akses terhadap ikan sebesar sebesar Rp 16.800/kg. Rata-rata responden memiliki akses terhadapminyak dan lemak sebesar Rp 12.600/kg.

40 persen responden rata-rata meiliki tabungan lebih dari 10 unit dan apabila dijual besarnya lebih dari Rp 2.000.000 (mampu). Rata-rata responden memiliki pengeluaran terhadap beras sebesar Rp 93.000. Semua responden tidak memiliki pengeluaran terhadap umbi-umbian. Rata-rata responden memiliki pengeluaran terhadap gula dan produk olahan sebesar Rp 41.900. Semua responden tidak memiliki pengeluaran terhadap biji berminyak. Rata-rata responden memiliki pengeluaran terhadap buah-buahan sebesar Rp 23.200. Ratarata responden memiliki pengeluaran terhadap sayuran sebesar Rp 17.500. Rata-rata responden memiliki pengeluaran terhadap daging sebesar $\mathrm{Rp}$ 99.600. Rata-rata responden memiliki pengeluaran terhadap telur sebesar Rp 6700. Ratarata responden memiliki pengeluaran terhadap ikan sebesar Rp 12.800. Rata-rata responden memiliki pengeluaran terhadap minyak dan lemak sebesar 31.100. semua responden tidak memiliki pengeluaran terhadap pakaian. Rata-rata responden memiliki pengeluaran terhadap pendidikan sebesar Rp 221.000. Rata-rata responden memiliki pengeluaran terhadap kesehatan sebesar Rp 55.000. Rata-rata responden memiliki pengeluaran terhadap listrik air telepon sebesar Rp 85500. Rata-rata responden memiliki pengeluaran terhadap bbm sebesar Rp 22600. Rata-rata responden memiliki pengeluaran terhadap sabun kosmetik sebesar Rp 17000. Rata-rata responden memiliki pengeluaran terhadap rehab rumah sebesar Rp 203500. Ratarata responden memiliki pengeluaran terhadap kegiatan social sebesar Rp 60000. Rata-rata responden memiliki pengeluaran terhadap transportasi sebsar Rp 265800. Rata-rata responden memiliki pengeluaran terhadap pajak kendaraan sebesar Rp 270000. Semua responden tidak memiliki pengeluaran terhadap rekresiasi hiburan.

\section{Hasil Uji Validitas dan Reliabilitas}

Pada penelitian ini terdapat 11 variabel yang terdiri dari identitas responden, karakteristik petani, indikator keberlanjutan kelembagaan, perilaku komunikasi, kemerosotan, persepsi tentang ciri-ciri inovasi, prosedur operasional standar (SOP) budidaya padi organic, modal social dan ketahanan pangan. Hasil uji validitas dan reliabilitas sebagaimana disajikan dalam Lampiran 1 menunjukkan bahwa terdapat 8 variabel dengan beberapa item-item pernyataan yang sudah valid dan reliable. Item pernyataan dinyatakan valid apabila nilai $\mathrm{R}$ hitung lebih besar daripada nilai R Tabel. Nilai R Tabel yaitu 0,5214 adapun nilai-nilai $\mathrm{R}$ hitung untuk item-item pernyataan yang valid dan reliable tertuang dalam Lampiran 3.

Item-item pernyataan yang sudah valid dan reliable tersebut meliputi variabel karakteristik petani dengan item pernyataan yaitu status keanggotaan petani. Variable indikator keberlanjutan kelembagaan yakni kinerja kelompok dengan item pernyataan yaitu responden menjual padinya ke gapoktan, responden menerapkan sistem peranian organik karena sesuai dengan aturan kelompok tani, responden memproduksi dengan kualitas sesuai dengan standar gapoktan, bertani padi organik menjadi sumber nafkah utama, bahan-bahan alami mudah diperoleh untuk membuat pupuk organik, responden percaya bahwa gapoktan dapat mengelola penjualan padi organik hasil panennya, menurut responden menjual padi organic ke gapoktan adalah yang utama, mendahulukan untuk menjual padi organic saya ke gapoktan, peraturan penjualan padi organik disepakati antara petani anggota kelompok dan pengurus Gapoktan, peraturan penjualan padi organik disepakati antara petani anggota kelompok dan pengurus Gapoktan, peraturan penjualan padi organik disepakati antara ketua kelompok dan pengurus Gapoktan.

Pada indicator keberhasilan penjualan padi organic ditentukan oleh PPL, tokoh masyarakat, pembeli di luar negeri, dan ketua CV. Pada indikator tata kelola, item pernyataan valid dan reliabel yaitu bahwa responden memiliki fotocopi bukti sertifikasi nasional, responden memiliki laporan perkembangan penjualan dari pengurus Gapoktan, dan responden bersedia lahan padi organik saya disertifikasi internasional. Pada variabel perilaku komunikasi dengan item pertanyaan yaitu bahwa responden memiliki intensitas interaksi dengan PPL. Pada variabel konteks kelembagaan dengan item pertanyaan yaitu bahwa responden menjadi anggota kelompok tani. Pada variabel kemerosotan yang termasuk dalam persepsi tentang ciri-ciri inovasi dengan 
item pernyataan yaitu responden akan terus aktif dalam kegiatan tani, responden segera menyelesaikan permasalahan yang muncul dalam kelompok, tanah semakin subur, kelompok lain di luar gapoktan, lembaga sertifikasi nasional, lembaga sertifikasi internasional, CV/Perusahaan, pembeli di luar negeri, dan responden kenal dengan pejabat pemerintah pusat. Pada variabel prosedur operasional standar (SOP) budidaya padi organik dengan item pernyataan responden mampu memutus siklus hama penyakit tanaman dan keadaan hama ada dalam batas tidak membahayakan.

\section{Rencana Tahapan Berikutnya}

Pada tahapan ini, dari hasil penjajagan, wawancara, focuss group discussion, hasil uji validitas dan reliabilitas dan reliabilitas dikemukakan dalam perkembangan sistem pertanian organik di Kabupaten Tasikmalaya, Kabupaten Malang, dan Kabupaten Boyolali. Dari uraian tersebut, penelitian ini sudah menghasilkan identifikasi awal dan pemetaan aktor yang terlibat dalam sistem pertanian organik pada kondisi terkini, identifikasi awal dan analisis kelembagaan yang terbangun dalam sistem pertanian organik pada kondisi terkini, identifikasi awal dan analisis faktor-faktor yang mempengaruhi keberlanjutan kelembagaan yang terbangun dalam sistem pertanian organik, identifikasi awal dan analisis konflik dalam pengembangan sistem pertanian organik, hasil analisis awal tingkat ketahanan pangan khususnya padi organik di lokasi penelitian.

Adapun rencana untuk tahapan berikutnya adalah melakukan revisi kuesioner, menyebarkan kuesionerke tiga lokasi penelitian, melakukan wawancara mendalam dan focuss group discussion di gabungan kelompok tani organik di Kabupaten Boyolali. Setelah data primer dari Kabupaten Boyolali terkumpul, kegiatan selanjutnya adalah mengolah data dari pengisian kuesioner dengan SPSS dan mengolah data kualitatif dengan analisis deskriptif. Setelah pengolahan data, maka dilanjutkan dengan penyusunan draft laporan akhir. Adapun pada tahapan berikutnya adalah menyusun rumusan model manajemen konflik berbasis komunitas dalam rangka membangun kelembagaan berkelanjutan menuju ketahanan pangan, serta membuat publikasi artikel di jurnal nasional terakreditasi sebagaimana yang tersaji selengkapnya dalam Tabel 6. Lebih lanjut pada tahun kedua, penelitian ini akan dilanjutkan dengan mengidentifikasi actor dan analisis kelembagaan dalam sistem pertanian non organik di sekitar lokasi penelitian, menganalisis proses sosialisasi dan implementasi manajemen konflik berbasis komunitas dalam rangka perluasan system pertanian organic menuju kedaulatan pangan, dan menyusun publikasi artikel di jurnal nasional terakreditasi.

\section{KESIMPULAN DAN SARAN}

Temuan sementara terkait dengan perkembangan pertanian organic di Kabupaten Tasikmalaya adalah kurangnya konformitas antara kelompok-kelompok tani dengan Gapoktan Simpatik, ketidakterbukaan dalam pengelolaan Gapoktan Simpatik memunculkan terjadinya penyimpangan dalam relasi kelompok tani dengan Gapoktan, kelembagaan pertanian organik di Kabupaten Tasikmalaya rentan untuk tidak berkelanjutan, dan purwadaksi menjadi nilai, norma, dan tata aturan serta kontrol sosial yang mendukung keberlanjutan kelembagaan pertanian organik. Adapun dari uraian perkembangan pertanian organic di Kabupaten Malang, maka sementara dapat diinterpretasikan bahwa tampaknya, faktor kepemimpinan (leadership) serta partisipasi anggota kelompok tani pertanian organik menjadi dua faktor penting kekuatan kelembagaan pertanian organik di Desa Sumber Ngepoh.

Lebih lanjut, perlu didalami "potensi konflik" tentang: Batasbatas penguasaan lahan dalam pertanian organik, antara penguasaaan lahan pertanian organik dan pertanian nonorganik (semi organik);Perbedaan persepsi (pandangan) antara kelompok petani yang telah melaksanakan pertanian organik dan yang belum melaksanakan pertanian organik (semi organik); Pemanfaatan sumber mata air (empat sumber mata air) untuk pengelolaan pertanian (padi) sawah khususnya antara pertanian organik dan pertanian nonorganik. Hasil penelitian Furaidah dan Retnaningdyah (2013) menyimpulkan bahwa berdasarkan nilai Hi dan FBI dari makroinvertebrata bentos, pencemaran bahan organik di air irigasi pertanian anorganik lebih tinggi dibandingkan pertanian organik. Dengan demikian kualitas air irigasi pertanian organik lebih baik dibandingkan air irigasi pertanian organik; Keperluan investor dalam pengembangan usaha pariwisata Sumber Mata Air Krabyaan seluas 15 Ha lahan dan aktual lahan yang dibutuhkan tersebut merupakan lahan pertanian organik; Persaingan pemenuhan tenaga kerja antara kebutuhan pertanian organik dan kebutuhan industri rumahtangga pembuatan atau "nancep bulu" pembuatan suttlecock.

Selain itu, juga perlu didalami hubungan antara aparatur pemerintahan Desa Sumber Ngepoh dengan kelompok tani dan Gapoktan pertanian organik. BUMDES tidak dikonstruksikan berlandaskan kelembagaan pertanian organik, yang tidak hanya sudah memiliki "pengalaman pembelajaran" dalam produksi pertanian organik, tetapi juga sudah memiliki "pengalaman pembelajaran" dalam merintis bisnis pertanian oraganik di sektor on-farm dan off-farm.

Berdasarkan pemahaman lebih rinci mengenai "potensi konflik" tersebut di atas maka perlu dielaborasi suatu pertanyaan penelitian "Bagaimana pendekatan konflik berbasis komunitas dalam pengembangan kelembagaan pertanian organik yang berkelanjutan" untuk studi kasus di Desa Sumber Ngepoh, Kecamatan Lawang, Kabupaten Malang, Provinsi Jawa Timur. Oleh karena itu, wawancara mendalam kepada informan diarahkan untuk memahami potensi konflik tersebut di atas, yang kemudian dalam FGD 12-15 orang partisipan diarahkan pembahasan mengenai pandangan subyektif komunitas Desa Sumber Ngepoh dalam mengelola potensi konflik untuk memberdayakan masyarakat Desa Ngepoh untuk menciptakan kelembagaan pertanian organik yang berkelanjutan.

\section{DAFTAR PUSTAKA}

Brinkerhoff, Derick W. And Arthur A. Goldsmith. 1992. "Promoting The Sustainability Of Development Institutions : A Framework Of Strategy”. World Development, Vol. 20, No. 3, Pp. 369-383.

Cernea, Michael M. 1993. The Sociologist's Approach To Sustainable Development. Paper Series No. 2, World Bank.

Gale, R.P And S. M. Corday. 1994. "Making Sense Of Sustainability : Nine Answer To What Should Be Sustained”. Rural Sociology 59 : 311-332.

Lele, S. 1991. Sustainable Development : A Critical Review. World Development, Vol. 19. No. 6. Pp. 607-621.

Henny Mayrowani 2012. Pengembangan Pertanian Organik Di Indonesia. Forum Penelitian Agro Ekonomi, Volume 30 
No. 2, Desember $2012: 91$ - 108

Ropke, Jochen 1986. Perkembangan Pertanian Dan Perubahan Hak Mengikuti Panen Di Asia Tenggara : Budidaya Padi Di Jawa. Yayasan Obor Indonesia. (Hal. 173 - 196): Jakarta.

Salikin, Karwan A. 2003. Sistem Pertanian Berkelanjutan. Penerbit Kanisius: Yogyakarta.

Scott, Richard W 2008. Institutions And Organization : Ideas And Interest. Third Edition. Sage Publications: London.

Wangsit, St Dan Daniel Supriyana 2003. Belajar Dari Petani : Kumpulan Pengalaman Bertani Organik. Sptn-HpsLesman-Mitra Tani: Yogyakarta.

Padmanabhan, Martina And Volker Beckman. 2009. Institution And Sustainability : Introduction And Overview. In Book: Institution And Sustainability : Political Economy Of Agriculture And The Environment : Essay In Honour Of Konrad Hagedorn. Springer: London.

Lockeretz, William. 2011. What Explain The Rise Of Organic Farming ?. In Book : Organic Farming : An Internasional History. Www.Cabi.Org: India.

Knight, Jack 1992. Institution and Social Conflict. Cambridge University Press: New York.

Syahyuti 2014. Mau Ini Apa itu : Komparasi Konsep, Teori, dan Pendekatan dalam Pembangunan Pertanian dan Pedesaan (125 versus 125). Amplitudo Media Science: Jakarta.

Indriana, Hana 2004. Penerapan Teknik Pertanian Organik Pada Budidaya Kentang. Kasus Pada Petani Kentang Di Kecamatan Pangalengan, Kabupaten Bandung: Skripsi. Institut Pertanian Bogor: Bogor.

Indriana, Hana 2010. Kelembagaan Berkelanjutan Dalam Pertanian Organik. Studi Kasus Pada Komunitas Petani Di Desa Mekarwangi, Desa Mekarwangi, Kecamatan Cisayong, Kabupaten Tasikmalaya: Tesis. Institut Pertanian Bogor. Bogor.

Azzuhro, Maslichah 2012. Pemberdayaan Komunitas Tani Dalam Penerapan Sistem Pertanian Organik (Studi Tiga Desa Binaan Bp3k Uptd Dramaga Kabupaten Tasikmalaya. Skripsi. Departemen Sains Komunikasi Dan Pengembangan Masyarakat. Fakultas Ekologi Manusia. Institut Pertanian Bogor: Bogor.
Harahap, Yeni Agustien 2014. Telaah Sosial Dan Ekonomi Petani Padi Organik. Skripsi. Departemen Sains Komunikasi Dan Pengembangan Masyarakat. Fakultas Ekologi Manusia. Institut Pertanian Bogor: Bogor.Deby, Cintya Aristy 2014. Faktor-Faktor Yang Mempengaruhi Sikap Petani Padi Sawah Terhadap Penerapan Pertanian Organik. Skripsi. Departemen Sains Komunikasi Dan Pengembangan Masyarakat. Fakultas Ekologi Manusia. Institut Pertanian Bogor: Bogor.

Putri, Nur Ivany 2011. Penerapan Teknologi Pertanian Padi Organik Di Kampung, Ciburuy, Desa Mekarwangi, Kecamatan Cisayong, Kabupaten Tasikmalaya. Skripsi. Departemen Sains Komunikasi Dan Pengembangan Masyarakat. Fakultas Ekologi Manusia. Institut Pertanian Bogor: Bogor.

Sebastian E. Saragih. Yp. Sudaryanto. Imam Hidayat. Gandi Bayu. Yayan Royan. Agung Alit. 2013. Merenda Asa Organik \& Fair Trade Di Indonesia : Keadila Untuk Petani Kecil Potret Pencari Keadilan. Aliansi Organis Indonesia. Bogor

Kartini, Ni Luh. Pelestarian Sda, Kunci Pertanian Berkelanjutan Dalam Kebijakan Pertanian. "Salam : Majalah Pertanian Berkelanjutan", No. 12 September 2005.

Nasdian, Fredian Tonny. 2014. Pengembangan Masyarekat. Pustaka Obor. Institut Pertanian Bogor: Bogor.

Lidya Ariesusanty, Sri Nuryati, Rasdi Wangsa 2013. Statistik Pertanian Organik Indonesia 2012. Aliansi Organis Indonesia. Bogor

Lidya Ariesusanty, Sri Nuryati, Rasdi Wangsa 2014. Statistik Pertanian Organik Indonesia 2013. Aliansi Organis Indonesia. Bogor

Indro Surono. Slamet. Theresia Eko Setyowati. Novrizal. Tommy Mulyadi. Thomas Irawan Sihombing. M. Tahir. Alhmad Arif. Yuli S. 2013. Mozaik Ics Dalam Pertanian Organik. Aliansi Organis Indonesia. Bogor

Peraturan Menteri Pertanian Nomor 64/Permentan/ Ot.140/5/2013 Tentang Sistem Pertanian Organik

http://www.malangkab.go.id/site/read/detail/107/kabupatenmalang-dalam-angka.html

https://tasikmalayakab.bps.go.id/

https://boyolalikab.bps.go.id/website/pdf_publikasi/BoyolaliDalam-Angka-2015.pdf 
Tabel 3. Tujuan, Jenis data yang Dibutuhkan, Teknik Pengumpulan Data, Teknik Analisis Data, dan Langkah-Langkah Analisis Data

\begin{tabular}{|c|c|c|c|c|}
\hline Tujuan & $\begin{array}{c}\text { Jenis data yang } \\
\text { dibutuhkan }\end{array}$ & $\begin{array}{c}\text { Teknik } \\
\begin{array}{c}\text { Pengumpulan } \\
\text { data }\end{array} \\
\end{array}$ & $\begin{array}{c}\text { Teknik } \\
\text { Analisis } \\
\text { Data } \\
\end{array}$ & Langkah-Langkah Analisis Data \\
\hline $\begin{array}{l}\text { 1. Mengidentifikasi dan } \\
\text { pemetaan actor yang } \\
\text { terlibat dalam system } \\
\text { pertanian organic pada } \\
\text { kondisi terkini }\end{array}$ & $\begin{array}{l}\text { Para pelaku baik } \\
\text { individu maupun } \\
\text { lembaga yang terlibat } \\
\text { dalam pertanian } \\
\text { organic di } 3 \text { lokasi } \\
\text { penelitian }\end{array}$ & $\begin{array}{l}\text {-wawancara } \\
\text {-analisis data } \\
\text { sekunder } \\
\text {-FGD }\end{array}$ & $\begin{array}{l}\text { Deskriptif } \\
\text { analisis, } \\
\text { social } \\
\text { mapping, } \\
\text { sosiogram }\end{array}$ & $\begin{array}{l}\text { 1. Transkrip hasil wawancara } \\
\text { 2. Menggambarkan struktur, } \\
\text { kultur, dan pola-pola relasi yang } \\
\text { dibangun antar actor } \\
\text { 3. Bersama subyek penelitian dan } \\
\text { informan membuat sosiogram }\end{array}$ \\
\hline $\begin{array}{l}\text { 2. Mengidentifikasi } \\
\text { dan menganalisis } \\
\text { kelembagaan yang } \\
\text { terbangun dalam } \\
\text { system pertanian } \\
\text { organic pada kondisi } \\
\text { terkini }\end{array}$ & $\begin{array}{l}\text { Penjelasan norma, } \\
\text { tata aturan, regulasi } \\
\text { yang mengatur relasi } \\
\text { antar aktor }\end{array}$ & $\begin{array}{l}\text { wawancara } \\
\text {-FGD }\end{array}$ & $\begin{array}{l}\text { Deskriptif } \\
\text { analisis } \\
\text { Diagram } \\
\text { venn }\end{array}$ & $\begin{array}{l}\text { 1. } \begin{array}{l}\text { Merumuskan bagan hubungan } \\
\text { antar pihak dengan menyusun }\end{array} \\
\text { Diagram Venn : } \\
\text { Sumber : (Teknik-Teknik PRA, } \\
\text { Prasodjo 2012). } \\
\text { 2. Memetakan derajat kepentingan } \\
\text { dan derajat kemanfaatan actor } \\
\text { terhadap komunitas padi organik }\end{array}$ \\
\hline $\begin{array}{l}\text { 3. Mengidentifikasi } \\
\text { dan menganalisis } \\
\text { faktor-faktor yang } \\
\text { mempengaruhi } \\
\text { keberlanjutan } \\
\text { kelembagaan yang } \\
\text { terbangun dalam } \\
\text { system pertanian } \\
\text { organic }\end{array}$ & $\begin{array}{l}\text { Factor internal dan } \\
\text { eksternal sehingga } \\
\text { kelembagaan } \\
\text { pertanian organic } \\
\text { mencapai } \\
\text { keberlanjutan hingga } \\
\text { mampu membuka } \\
\text { jejaring kerjasama } \\
\text { internasional }\end{array}$ & $\begin{array}{l}\text {-wawancara } \\
\text { dengan } \\
\text { menggunakan } \\
\text { kuesioner } \\
\text { terstruktur }\end{array}$ & $\begin{array}{l}\text { Analisis } \\
\text { statistic } \\
\text { regresi } \\
\text { liner dan } \\
\text { Deskriptif } \\
\text { analisis }\end{array}$ & $\begin{array}{l}\text { 1. Menyusun kuesioner } \\
\text { 2. Uji coba kueioner } \\
\text { 3. Mengukur validitas dan } \\
\text { reliabilitas data } \\
\text { 4. Pengisian kuesioner oleh } \\
\text { responden } \\
\text { 5. Uji statistic dengan analisis } \\
\text { regresi linier }\end{array}$ \\
\hline $\begin{array}{l}\text { 4. Mengidentifikasi dan } \\
\text { menganalisis konflik } \\
\text { dalam pengembangan } \\
\text { system pertanian } \\
\text { organic }\end{array}$ & $\begin{array}{l}\text { Jenis-jenis konflik } \\
\text { yang terjadi } \\
\text { dalam dinamika } \\
\text { pengembangan } \\
\text { pertanian organic di } 3 \\
\text { lokasi penelitian } \\
\text { Dan penjelasan } \\
\text { subyek penelitian } \\
\text { mengenai } \\
\text { mekanismen } \\
\text { manajemen konflik } \\
\text { berbasis komunitas }\end{array}$ & $\begin{array}{l}\text {-penelusuran } \\
\text { data sekunder } \\
\text {-wawancara } \\
\text { mendalam } \\
\text { dengan } \\
\text { menggunakan } \\
\text { panduan } \\
\text { pertanyaan }\end{array}$ & $\begin{array}{l}\text { Deskriptif } \\
\text { analisis }\end{array}$ & $\begin{array}{l}\text { Pengorganisasian Masalah: } \\
\text { 1. Menyusun kembali masalah } \\
\text { 2. Menyeleksi masalah } \\
\text { 3. Melihat hubungan sebab-akibat } \\
\text { dari masalah } \\
\text { 4. Mendiskusikan prioritas masalah } \\
\text { 5. Menggali dan menganalisa } \\
\text { alternatif pemecahan masalah }\end{array}$ \\
\hline $\begin{array}{l}\text { 5. Menganalisis tingkat } \\
\text { ketahanan pangan } \\
\text { khususnya padi organic } \\
\text { di lokasi penelitian }\end{array}$ & $\begin{array}{l}\text { Tingkat } \\
\text { ketersediaan beras } \\
\text { organic pada periode } \\
\text { tertentu } \\
\text { - Jangkauan } \\
\text { distribusi beras } \\
\text { organic, jumlah } \\
\text { konsumen dan jumlah } \\
\text { pembelian }\end{array}$ & $\begin{array}{l}\text { wawancara } \\
\text { dengan } \\
\text { menggunakan } \\
\text { kuesioner }\end{array}$ & $\begin{array}{l}\text { Analisis } \\
\text { distribusi } \\
\text { frekuensi }\end{array}$ & $\begin{array}{l}\text { 1. Menyusun kuesioner } \\
\text { 2. Uji coba kueioner } \\
\text { 3. Mengukur validitas dan } \\
\text { reliabilitas data } \\
\text { 4. Pengisian kuesioner oleh } \\
\text { responden } \\
\text { 5. Uji statistic dengan analisis } \\
\text { distribusi frekuensi }\end{array}$ \\
\hline $\begin{array}{l}\text { 6. Merumuskan } \\
\text { model manajemen } \\
\text { konflik berbasis } \\
\text { komunitas dalam } \\
\text { rangka membangun } \\
\text { kelembagaan } \\
\text { berkelanjutan menuju } \\
\text { ketahanan pangan }\end{array}$ & $\begin{array}{l}\text { Data primer } \\
\text { mengenai actor, } \\
\text { relasi antar actor, } \\
\text { kelembagaan dan } \\
\text { keberlanjutannya, } \\
\text { tingkat ketahanan } \\
\text { pangan dan } \\
\text { mekanisme } \\
\text { manajemen konflik } \\
\text { yang sudah dilakukan }\end{array}$ & $\begin{array}{l}\text { Hasil } \\
\text { wawancara } \\
\text { mendalam, } \\
\text { pengisian } \\
\text { kuesioner, } \\
\text { observasi, } \\
\text { dan } \\
\text { pengambatan } \\
\text { berperan serta }\end{array}$ & $\begin{array}{l}\text { Analisis } \\
\text { studi kasus } \\
\text { dilengkapi } \\
\text { dengan data } \\
\text { kuantitatif }\end{array}$ & $\begin{array}{l}\text { Pengolahan data kualitatif dengan } \\
\text { transkrip hasil wawancara mendalam } \\
\text { dan pengolahan data kuantitatif } \\
\text { dengan uji statistik menggunakan } \\
\text { SPSS. }\end{array}$ \\
\hline
\end{tabular}

